\title{
EXPLORING THE POSSIBILITIES OF STEEL-FIBER REINFORCED SELF-COMPACTING CONCRETE FOR THE FLEXURAL STRENGTHENING OF MASONRY STRUCTURAL ELEMENTS
}

\author{
Dustin Häßler ${ }^{1}$ and Joaquim A. O. Barros ${ }^{2}$ \\ ${ }^{1}$ Department of Civil Engineering, Minho University, Guimarães, Portugal \\ ${ }^{2}$ ISISE, Department of Civil Engineering, Minho University, Guimarães, Portugal
}

The potentialities of a thin layer of steel-fiber reinforced self-compacting concrete (SFRSCC) for the flexural strengthening of handmade brick structural elements are investigated. For this purpose, an experimental program was carried out covering the relevant phenomena that can influence the effectiveness of this technique. The SFRSCC has a post-cracking residual tensile strength capable of improving the flexural stiffness, flexural resistance and ductility of prototypes representatives of ancient handmade brick based structures that fail in bending. To appraise the flexural strengthening effectiveness of this technique, straight beams composed of handmade bricks, low-strength mortar (LSM) and SFRSCC were tested. The obtained results have shown that this technique can increase significantly the flexural stiffness and resistance, and the ductility performance of this type of structures. The strengthening effectiveness depends on the post-cracking residual strength of the SFRSCC, its layer thickness and on the possibility of replacing part of the LSM by SFRSCC. Based on the experimental results for the characterization of the intervening materials, and adopting a cross section layer model capable of predicting the moment-curvature relationship for the distinct types of cross sections of this structural system, the maximum load registered in the tested prototypes was predicted with good accuracy.

KEY WORDS: Steel-fiber reinforced self-compacting concrete, Flexural strengthening technique, Masonry structural elements, Handmade bricks, Material tests, Bond, Fracture properties

\section{INTRODUCTION}

Numerous historical constructions are still in use all over the world and a significant part of them has cultural and artistic value. The structural strengthening of historical masonry buildings can be justified by the damage in their constituent materials or when extra strength and ductility is required to prevent their local or total collapse when submitted to natural events, like an earthquake. Steel-fiber reinforced self-compacting concrete (SFRSCC) is a quite flowable cement-based ductile material, with a post-cracking residual tensile strength that can be engineered to fit required levels of strength and ductility (Pereira et al. 2008; Shah and Ferrara, 2008). A thin layer of SFRSCC can be bonded to brick-based

Received February 15, 2011; accepted June 15, 2011.

Address correspondence to Joaquim A. O. Barros, ISISE, Department of Civil Engineering, Minho University, Campus de Azurém, 4800-058, Guimarães, Portugal. E-mail: barros@ @ivil.uminho.pt 
ancient buildings in order to significantly increase the load and energy dissipation capacity of this type of constructions.

To assess the possibilities of using a self-compacting concrete (SCC) reinforced with a relatively low content of steel fibers to increase the flexural resistance of this type of structures, straight beam prototypes of brick/mortar/SFRSCC were tested experimentally. The relevant properties of the constituent materials were determined from experimental research, such as: fracture parameters of bricks and SFRSCC, compressive and tensile strength of all applied materials, bond strength between brick and SFRSCC, and between mortar and SFRSCC. Using the data derived from the experimental tests and using a crosssection layer model that has constitutive laws for the simulation of the relevant aspects of the behavior of the intervening materials (Basto and Barros, 2008), the load-carrying capacity of the tested beams was predicted.

\section{PROPERTIES OF THE CONSTITUENT MATERIALS}

\subsection{Introduction}

The experimental program consist of tests for the characterization of the: compression and flexural behavior of bricks; compression, flexural and axial tensile behavior of SFRSCC; compression and flexural behavior of low-strength mortar (LSM) used to bond bricks; bond strength of brick-SFRSCC and mortar-SFRSCC. This chapter describes the testing programs, and presents and discusses their results. More details can be found at Häßler (2010).

\subsection{Bricks}

Burnt bricks have been used for millennia as an alternative for natural stones in areas where stones are rare, such as big river valleys. Archaeological evidence suggests that fired bricks were already used five thousand years ago in the Middle East and Far East. In Europe, the Greeks and the Romans established the use of brick stones. (Krausz, 2002). The handmade bricks used in the present research program have dimensions of $205 \mathrm{~mm} \times$ $105 \mathrm{~mm} \times 55 \mathrm{~mm}(\mathrm{~L} \times \mathrm{W} \times \mathrm{H})$ and were collected from six Portuguese monasteries (Fernandes and Lourenço, 2007). Due to the anisotropic material behavior of the brick, its properties were determined in the directions of the coordinate system X, Y, and Z. The $\mathrm{X}$ and $\mathrm{Z}$ directions correspond to the longest and to the shortest dimension of the brick, respectively. Three point bending tests were performed to determine the flexural tensile strength and the fracture energy of this type of bricks. The bending tests were carried out according to the German DIN EN 1015-11 standard (German Institute for Standardization, 2007). From one brick unit two specimens were extracted with dimensions of $160 \mathrm{~mm}$ $\times 40 \mathrm{~mm} \times 40 \mathrm{~mm}(\mathrm{~L} \times \mathrm{W} \times \mathrm{H})$. Since the surfaces of the bricks were uneven, the specimens were cut out from the centre of the brick unities by using a diamond disk. In total, fourteen brick specimens were prepared, seven of those were used to determine the flexural tensile strength of the brick material, and the other seven for the evaluation of the fracture energy. The experimental setup is represented in Figure 1. The distance between the supports is $100 \mathrm{~mm}$. The test was performed under displacement control at a velocity of $1 \mu \mathrm{m} / \mathrm{s}$. A load cell of $50 \mathrm{kN}$ with an accuracy of $0.05 \%$ was attached to the actuator. In the centre of the brick's beam a linear variable differential transformer (LVDT) was placed to measure the vertical displacement at the middle of the beam. In general, 
(a)

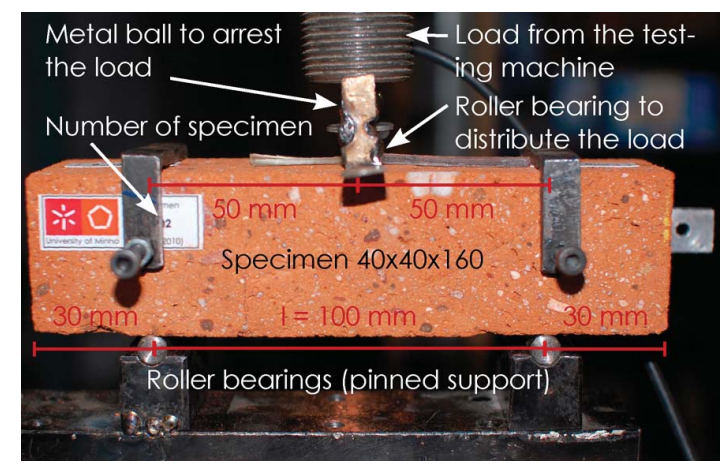

(b)

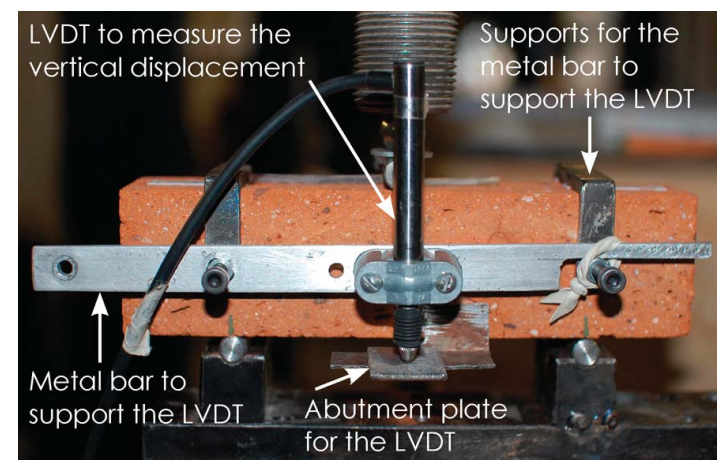

Figure 1. Photograph of the experimental setup for the three-point bending test with unnotched brick specimens: (a) front side; and (b) back side (axis of the beam coincides with the $\mathrm{X}$ direction) (color figure available online).

the specimens have failed by the formation of a vertical crack in the centre of the brick beam. The flexural tensile strength in the $\mathrm{X}$ direction, $f_{t, f}$, (the longitudinal stresses due to bending are in the $X$ direction) has ranged between $0.87 \mathrm{~N} / \mathrm{mm}^{2}$ and $2.27 \mathrm{~N} / \mathrm{mm}^{2}$, and was calculated according to Equation 1:

$$
f_{t, f}=1.5 \cdot \frac{\left(F_{\max } \cdot l\right)}{b \cdot d^{2}}
$$

where $b$ and $d$ are the width and the depth of the specimen's cross-section, $l$ is the distance between supports, and $F_{\max }$ is the maximum applied force.

To obtain the fracture energy, $G_{f}$, of the clay bricks, a similar experimental setup was used. However, in the tested seven specimens, with dimensions equal to those specimens adopted for the evaluation of flexural tensile strength, a notch with a depth of approximately $15 \mathrm{~mm}$ was sawn in the middle of the brick specimen. The experimental setup was prepared according to the RILEM FCM1 standard, and is represented in Figure 2 (RILEM TC, 1994). In the notch, two metal plates were glued to support a horizontal LVDT for measuring the crack opening. A vertical LVDT was also applied in the centre of the specimen to measure the vertical displacement of brick's section at beam's mid-span. The test was also performed under displacement control at a deflection rate of $1 \mu \mathrm{m} / \mathrm{s}$. From the 


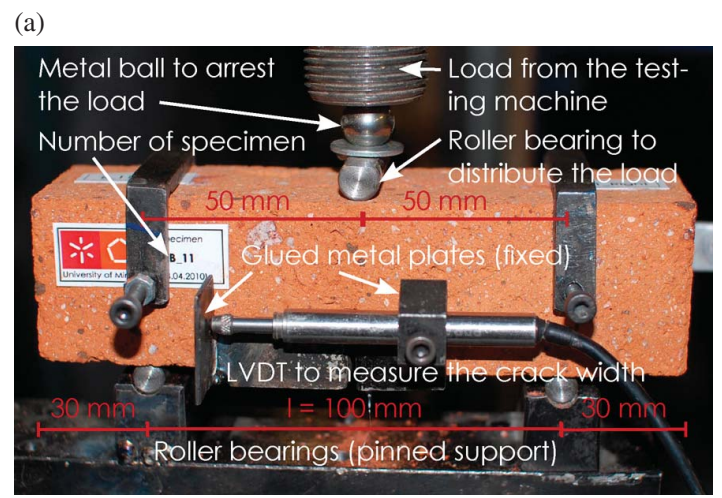

(b)

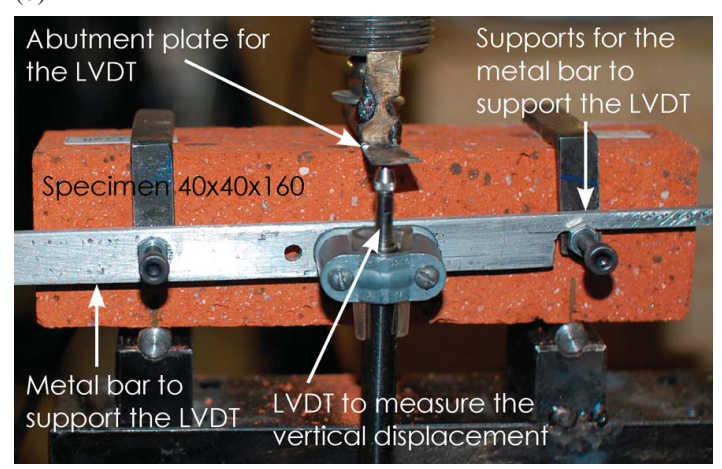

Figure 2. Photograph of the experimental setup for the three-point bending test with notched brick specimens: (a) front side; and (b) back side (axis of the beam coincides with the $\mathrm{X}$ direction) (color figure available online).

area under the force versus vertical displacement diagram $\left(W_{0}\right)$, the fracture energy was calculated using the following equation (RILEM TC, 1994):

$$
G_{f}=\frac{\left(W_{0}+m \cdot g \cdot \delta_{0}\right)}{A_{\text {lig }}}
$$

where $m$ is the weight of the beam between the supports and the part of the loading arrangement, which is not attached to the equipment, but follows the brick until failure. In this equation, $g$ is the gravity acceleration, $\delta_{0}$ is the ultimate deflection (for $F=0$ ) and $A_{\text {lig }}$ is the area of the projection of the fracture zone on a plane perpendicular to the brick axis. The dispersion of the results $\left(f_{t, f}=0.87\right.$ to $2.27 \mathrm{~N} / \mathrm{mm}^{2} ; G_{f}=0.0355$ to $0.0532 \mathrm{~N} / \mathrm{mm}$ ) was quite high. This can be justified by the defects in the material, like voids and micro cracks, and from differences in the manufacturing process of the bricks, e.g. during the burning procedure. The average flexural tensile strength and fracture energy for the performed tests are shown in Table 1.

The experimental determination of the compressive strength and modulus of elasticity was executed by another research group (Marcari, Oliveira, and Lourenço, 2011), by performing tests with six specimens. The test setup consisted of a steel frame that 
Table 1. Average values determined from the experimental tests

\begin{tabular}{|c|c|c|c|c|c|}
\hline Material property & Symbol & Unit & $\begin{array}{l}\text { Values for steel-fibre } \\
\text { reinforced } \\
\text { self-compacting } \\
\text { concrete [SFRSCC] }\end{array}$ & $\begin{array}{l}\text { Values for } \\
\text { brick }\end{array}$ & $\begin{array}{c}\text { Values for } \\
\text { mortar (low } \\
\text {-strength } \\
\text { mortar [LSM]) }\end{array}$ \\
\hline Compressive strength & $\mathrm{f}_{\mathrm{cm}}$ & {$\left[\mathrm{N} / \mathrm{mm}^{2}\right]$} & $57.25(1.30)$ & $\begin{array}{l}12.35(2.18) \\
\quad[\mathrm{Z} \text { direction }]\end{array}$ & $16.06(1.58)$ \\
\hline $\begin{array}{l}\text { Compressive strain at } \\
\text { the peak stress }\end{array}$ & $\varepsilon_{\mathrm{c} 1}$ & - & $2.6 \times 10^{-3 * *}$ & $\begin{array}{l}7.1 \times 10^{-3 *} \\
\quad[\mathrm{Z} \text { direction }]\end{array}$ & $0.69 \times 10^{-3 *}$ \\
\hline $\begin{array}{l}\text { Maximum compressive } \\
\text { strain }\end{array}$ & $\begin{array}{l}\varepsilon_{\mathrm{c} \_l i m} \\
\left(2 \cdot \varepsilon_{\mathrm{c} 1}\right)\end{array}$ & - & $5.2 \times 10^{-3 *}$ & $\begin{array}{l}14.3 \times 10^{-3 *} \\
\quad[\mathrm{Z} \text { direction }]\end{array}$ & $1.4 \times 10^{-3 *}$ \\
\hline Modulus of elasticity & $\mathrm{E}_{\mathrm{cm}}$ & {$\left[\mathrm{N} / \mathrm{mm}^{2}\right]$} & $32717(925)$ & $\begin{array}{l}1729(575) \\
{[\mathrm{Z} \text { direction }]}\end{array}$ & $23220^{* * *}$ \\
\hline Fracture energy & $\mathrm{G}_{\mathrm{fm}}$ & {$[\mathrm{N} / \mathrm{mm}]$} & $2.439(1.616)$ & $\begin{array}{l}0.046(0.0098) \\
\quad[X \text { direction }]\end{array}$ & - \\
\hline Axial tensile strength & $\mathrm{f}_{\mathrm{tm}}$ & {$\left[\mathrm{N} / \mathrm{mm}^{2}\right]$} & $3.01(0.39)$ & $\begin{array}{l}0.99^{*} \\
\quad[\mathrm{X} \text { direction }]\end{array}$ & $2.58^{*}$ \\
\hline $\begin{array}{l}\text { Flexural tensile } \\
\text { strength }{ }^{\#}\end{array}$ & $\mathrm{f}_{\mathrm{tm}, \mathrm{fl}}$ & {$\left[\mathrm{N} / \mathrm{mm}^{2}\right]$} & $11.22^{* * * *}$ & $\begin{array}{l}1.54(0.45) \\
\quad[X \text { direction] }\end{array}$ & $4.03(0.32)$ \\
\hline $\begin{array}{l}\text { Equivalent flexural } \\
\text { tensile strength } \\
\text { parameters }\end{array}$ & $\begin{array}{c}\mathrm{f}_{\mathrm{eq}, 2} \\
\mathrm{f}_{\mathrm{eq}, 3}\end{array}$ & {$\left[\mathrm{~N} / \mathrm{mm}^{2}\right]$} & $\begin{array}{l}11.02 \\
10.23\end{array}$ & - & - \\
\hline $\begin{array}{l}\text { Residual flexural tensile } \\
\text { strength parameters }\end{array}$ & $\begin{array}{l}\mathrm{f}_{\mathrm{R}, 1} \\
\mathrm{f}_{\mathrm{R}, 4}\end{array}$ & {$\left[\mathrm{~N} / \mathrm{mm}^{2}\right]$} & $\begin{array}{l}10.57 \\
9.59\end{array}$ & - & - \\
\hline $\begin{array}{l}\text { Energy absorption } \\
\text { capacity }\end{array}$ & $\begin{array}{l}D_{B Z, 2}^{f} \\
D_{B Z, 3}^{f_{B}}\end{array}$ & {$[\mathrm{~N} \mathrm{~mm}]$} & $\begin{array}{l}17758 \\
82438\end{array}$ & - & - \\
\hline $\begin{array}{l}\text { Ultimate tensile crack } \\
\text { strain }\end{array}$ & $\varepsilon_{\mathrm{cr}}$ & - & - & $\begin{array}{l}5.72 \times \\
10^{-4 *}\end{array}$ & $1.11 \times 10^{-4 *}$ \\
\hline
\end{tabular}

\#The flexural tensile strength was not entered in the program, but it was used to derive the axial tensile strength for brick and mortar.

*These values were assumed or calculated from equations given in 'EC2' and 'DIN 1045-1'.

**The value for the compressive strain at peak stress was taken from a C50/60 (German Institute for Standardization, 2000, DIN 1045-1).

***Assumed from a concrete C12/15 (German Institute for Standardization, 2000, DIN 1045-1) because of the same compressive strength, but the value is reduced by $10 \%$ due to the absence of big aggregates.

****The flexural tensile strength for SFRSCC was obtained from the three-point bending test of a specimen with a $25 \mathrm{~mm}$ deep notch.

( . . . ) These values refer to the standard deviation of the tests.

supported a servo-controlled actuator with a load cell of $25 \mathrm{kN}$ capacity. To assess the brick's deformability, four LVDTs were placed as represented in Figure 3. The test was controlled by axial displacement with a velocity of $1 \mu \mathrm{m} / \mathrm{s}$ (Marcari et al. 2011). The average compressive strength and modulus of elasticity, both in $\mathrm{Z}$ direction, are included in Table 1.

\subsection{Mortar}

For the manufacturing of the mortar used to bond the bricks, sand with an aggregate size less than $1 \mathrm{~mm}$ and cement were weighted in the appropriate amounts and were mixed with water, in agreement to the mortar composition provided in Table 2. For the determination of the flexural tensile strength of the mortar, three-point-bending 


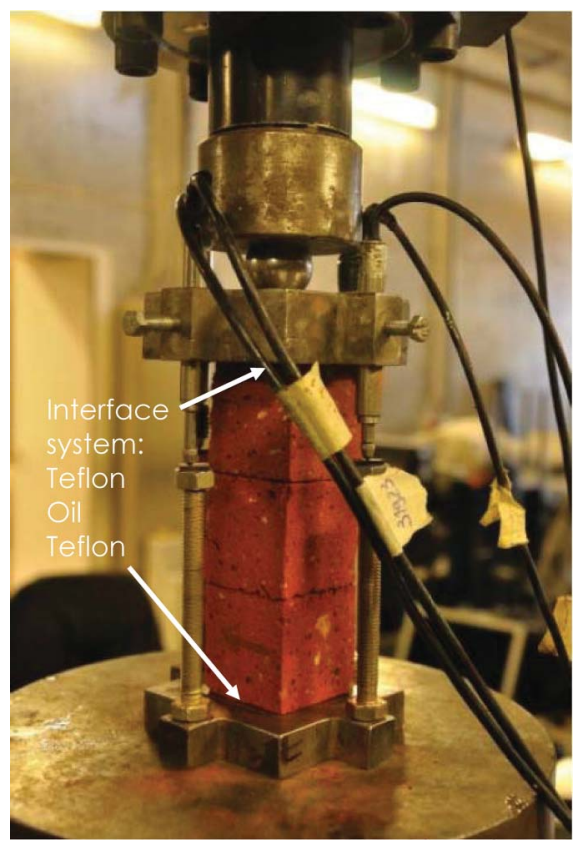

Figure 3. Photograph of the test setup for the compressive test of brick in $\mathrm{Z}$ direction (color figure available online).

Table 2. Mixing composition per liter of low strength mortar

\begin{tabular}{lccc}
\hline Mixture & Cement $($ CEM I 42.5 R) & Sand (Areia, $\mathrm{d}<1 \mathrm{~mm})$ & Water \\
\hline $1: 3: 0.75$ & 1 & 3 & 0.75 \\
& $716 \mathrm{~g}$ & $2148 \mathrm{~g}$ & $293 \mathrm{~g}+234 \mathrm{~g}$
\end{tabular}

tests were performed according to the DIN EN 1015-11 standard (German Institute for Standardization, 2007). The specimens had dimensions equal to those of the brick specimens in the bending tests $(160 \mathrm{~mm} \times 40 \mathrm{~mm} \times 40 \mathrm{~mm})$. The bending tests of the mortar specimens were performed by force control at a force rate of $30 \mathrm{~N} / \mathrm{s}$. Almost all of the six tested specimens failed by the formation of a vertical crack in the centre of the beam (Häßler, 2010). The flexural tensile strength was calculated from equation (2.1), and values ranging between $3.54 \mathrm{~N} / \mathrm{mm}^{2}$ and $4.45 \mathrm{~N} / \mathrm{mm}^{2}$ were obtained. The average value for the flexural tensile strength of mortar is indicated in Table 1.

The compression test was performed according to the DIN EN 1015-11 standard (German Institute for Standardization, 2007). For this test, the broken samples from the three-point bending test were used. The specimens were placed with the undamaged extremities in a steel frame, loaded up to failure under force control at a force rate of $100 \mathrm{~N} / \mathrm{s}$, and the maximum force was recorded. The failure of the specimens started abruptly through a cracking and spalling of the mortar. The determined values for the compressive strength ranged between $13.99 \mathrm{~N} / \mathrm{mm}^{2}$ and $18.27 \mathrm{~N} / \mathrm{mm}^{2}$. The average value for the compressive strength of mortar is provided in Table 1. 


\subsection{Steel-Fiber Reinforced Self-Compacting Concrete (SFRSCC)}

2.4.1. Mix composition and rheological properties Today, fiber-reinforced concrete (FRC) is widely used and finds its application in cases where a higher concrete post-cracking residual tensile strength can be used to increase the load-carrying capacity, the flexural stiffness and the ductility performance of a structural element (Balaguru and Shah, 1992; American Concrete Institute [ACI], 1996). In this work, a self-compacting concrete containing steel fibers was used, since the favorable characteristics of selfcompactability can be added to the benefits provided by fiber reinforcement in order to obtain a cement based material that can increase significantly the flexural load-carrying capacity, the stiffness and the ductility performance of handmade brick-based masonry structures failing in bending. The composition of the used SFRSCC is indicated in Table 3. Hooked ends steel fibers of $35 \mathrm{~mm}$ total length $\left(l_{f}\right), 0.55 \mathrm{~mm}$ diameter $\left(d_{f}\right)$, aspect ratio $\left(l_{f} / d_{f}\right)$ of 64 , and tensile strength of about $1100 \mathrm{MPa}$ were used in the manufacture of this SFRSCC. A slump flow of $760 \mathrm{~mm}$ and a T50 $=4$ seconds in the slump flow test, a $\mathrm{H} 2 / \mathrm{H} 1$ ratio of 0.8 in the LBox and a flow time of 9 seconds in the V Funnel were obtained for the developed SFRSCC (European Federation of National Associations Representing Producers and Applicators of Specialist Building Products for Concrete [EFNARC], 2002).

2.4.2. Compressive Behavior To determine the compressive strength, $f_{c}$, and the Young's modulus, $E_{c}$, of the SFRSCC, compression tests were performed with cylindrical specimens of $150 \mathrm{~mm}$ in diameter and $300 \mathrm{~mm}$ in height. To measure the axial deformability of the SFRSCC specimen, three LVDTs were placed around the specimen, forming an angle of $120^{\circ}$ between the LVDTs. The tests were carried out by displacement control at a velocity of $5 \mu \mathrm{m} / \mathrm{s}$. Five SFRSCC specimens were tested and their compression stress-strain relationships were obtained. The compressive strength ranged between $56.66 \mathrm{~N} / \mathrm{mm}^{2}$ and $58.98 \mathrm{~N} / \mathrm{mm}^{2}$, which means that the SFRSCC can be considered as pertaining to C50/60 strength class, according to the DIN 1045-1 standard (German Institute for Standardization, 2000). The average compressive strength of SFRSCC is indicated in Table 1.

For the determination of the Young's modulus, a holding device consisting of two rings was placed $100 \mathrm{~mm}$ apart in the middle part of the specimens to install the LVDTs used to measure the SFRSCC deformability between these two rings (Häßler, 2010). From the results, an $E_{c}$ ranging from $30681 \mathrm{~N} / \mathrm{mm}^{2}$ to $34779 \mathrm{~N} / \mathrm{mm}^{2}$ was obtained and the corresponding average value is shown in Table 1.

2.4.3. Tensile Behavior To determine the tensile strength of the SFRSCC, axial tensile tests were performed with specimens of $500 \mathrm{~mm} \times 100 \mathrm{~mm} \times 40 \mathrm{~mm}(\mathrm{~L} \times \mathrm{W} \times \mathrm{T})$ dimensions. These specimens were cut out from a previously manufactured SFRSCC panel with the dimensions of $2000 \mathrm{~mm} \times 1000 \mathrm{~mm} \times 40 \mathrm{~mm}(\mathrm{~L} \times \mathrm{W} \times \mathrm{T})$. The SFRSCC composition was the same as that already presented in Table 3 . To assess the influence of

Table 3. Steel-fibre reinforced self-compacting concrete (SFRSCC) mixing composition per $\mathrm{m}^{3}$ of concrete

\begin{tabular}{lccccccc}
\hline $\begin{array}{l}\text { Cement } \\
{[\mathrm{kg}]}\end{array}$ & $\begin{array}{c}\text { Water } \\
{[\mathrm{kg}]}\end{array}$ & $\begin{array}{c}\text { Superplasticizer } \\
{\left[\mathrm{dm}^{3}\right]}\end{array}$ & $\begin{array}{c}\text { Limestone } \\
\text { filler }[\mathrm{kg}]\end{array}$ & $\begin{array}{c}\text { Fine river } \\
\text { sand }[\mathrm{kg}]\end{array}$ & $\begin{array}{c}\text { Coarse river } \\
\text { sand }[\mathrm{kg}]\end{array}$ & $\begin{array}{c}\text { Crushed } \\
\text { granite }[\mathrm{kg}]\end{array}$ & $\begin{array}{c}\text { Hooked end steel } \\
\text { fibers }[\mathrm{kg}]\end{array}$ \\
\hline 380.54 & 111.14 & 6.09 & 326.17 & 368.12 & 567.95 & 510.06 & 45.00 \\
\hline
\end{tabular}




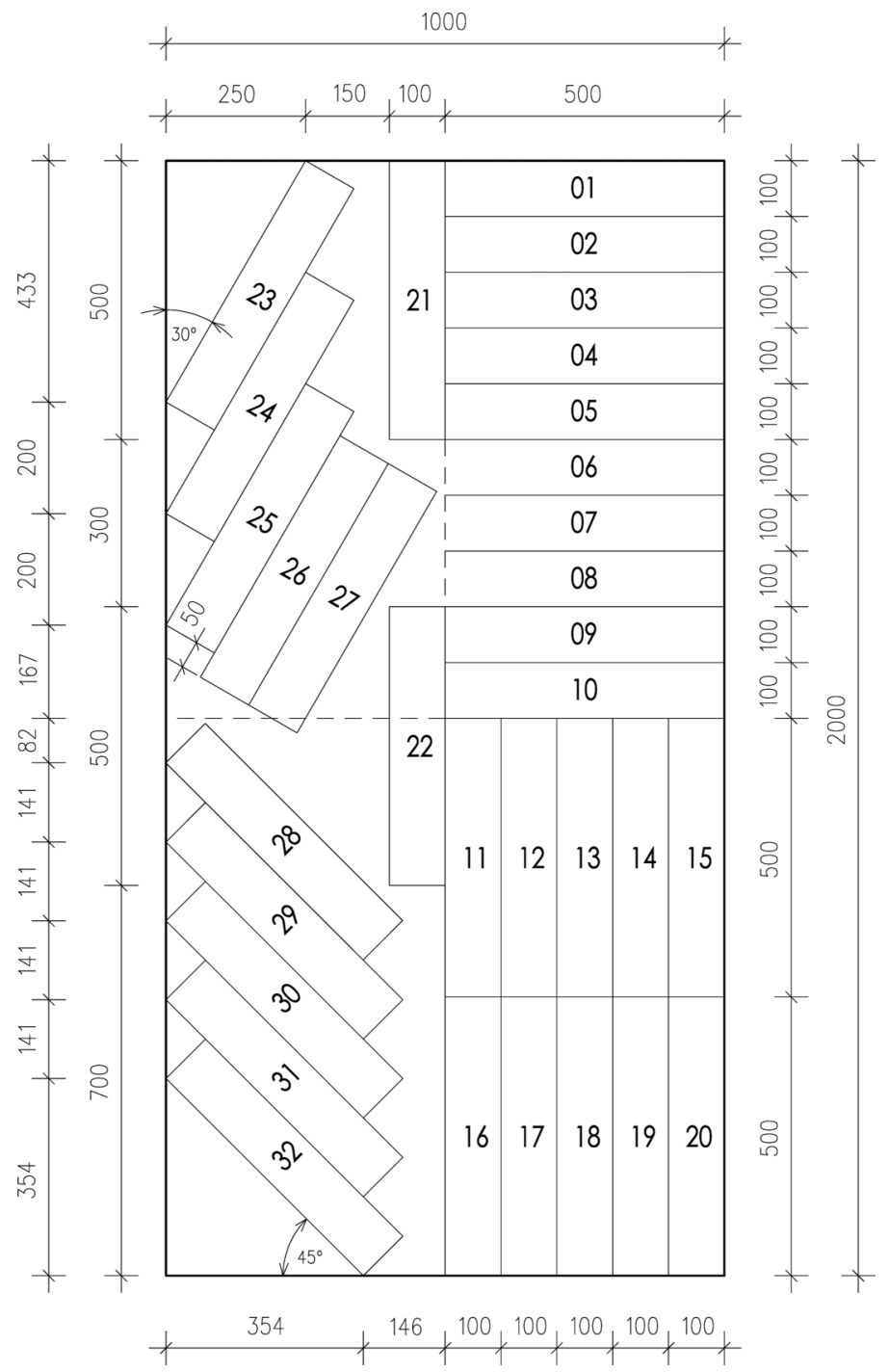

Figure 4. Drawing of the cutting pattern for the production of the steel-fibre reinforced self-compacting concrete (SFRSCC) specimens for the tensile tests (dimensions in $\mathrm{mm}$ ).

the fiber orientation on the tensile strength, the cutting process of the specimens was done in several directions: $0^{\circ}, 30^{\circ}, 45^{\circ}$, and $90^{\circ}$. The drawing of the cutting pattern can be seen in Figure 4. After measuring the cross-section of the specimens, they were individually fixed in the testing machine by means of ribbed clamps. The clamps allow the specimen to rotate in all directions (pinned ends conditions for the specimen). In contrast to smooth clamps, the ribbed clamping plates can properly interlock with the concrete. The clamps were tightened very firmly to avoid sliding. Nevertheless, despite the particularities of these clamps, some sliding occurred.

In an attempt of avoiding premature failure at the specimen's extremities due to stress concentrations introduced by the fixing procedures of the clamps, a layer of an epoxy-based 
adhesive with a thickness varying from 2 to $4 \mathrm{~mm}$ was applied in each face in contact with the clamps (Figure 5). However, some specimens have failed just near the clamps. Therefore, not all tests could be used to determine the tensile strength of the SFRSCC. An LVDT was mounted on one side of the specimen to measure the deformation of the SFRSCC during the tensile test (Figure 6). The test was displacement controlled at a velocity of $1 \mu \mathrm{m} / \mathrm{s}$. By reaching the maximum force, the specimens have cracked and the force has dropped to a value of 10 to 40 percent of the maximum force. From the maximum force and the cross-sectional area of the specimen $\left(\mathrm{A}_{\mathrm{C}}\right)$, the tensile strength of the SFRSCC was calculated, with the values between $2.42 \mathrm{~N} / \mathrm{mm}^{2}$ and $3.65 \mathrm{~N} / \mathrm{mm}^{2}$. The average value of the tensile strength is indicated in Table 1.

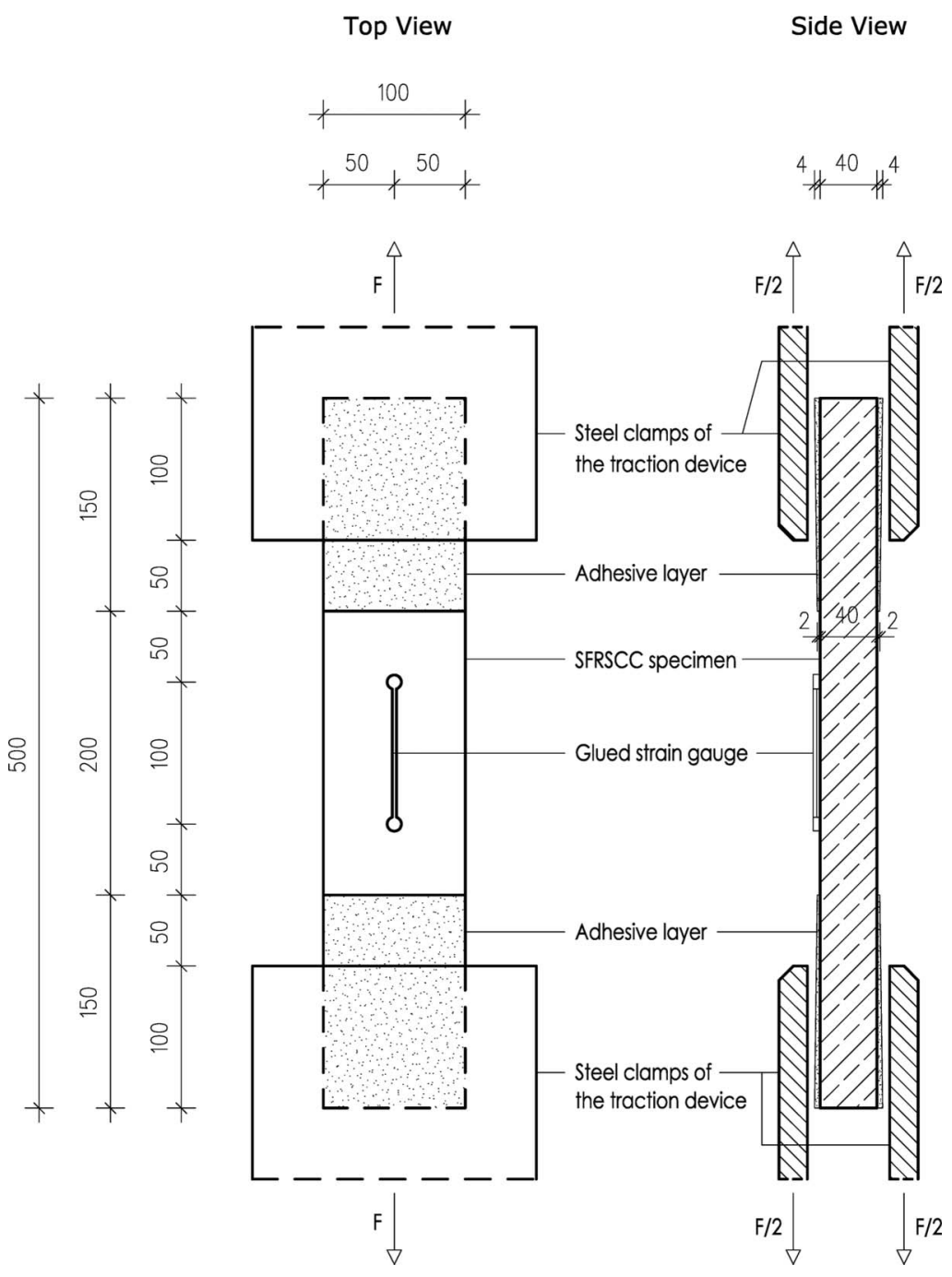

Figure 5. Drawing of the test setup for the determination of the tensile strength of steel-fibre reinforced self-compacting concrete (SFRSCC) (dimensions in $\mathrm{mm}$ ). 


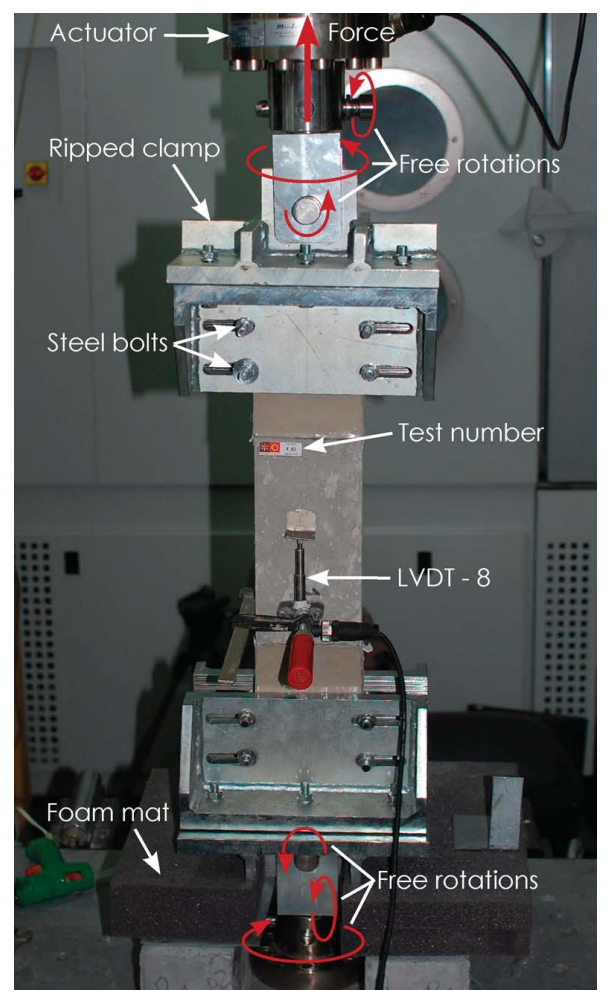

Figure 6. Photograph of a test apparatus for the evaluation of the steel-fibre reinforced self-compacting concrete (SFRSCC) tensile strength (color figure available online).

Taking into account the number of fibers bridging the fracture surface (Barros et al. 2005) it was concluded that the tensile strength has increased with the number of fibers, which was already observed in other experimental programs (Cunha, 2010; Oliveira 2010). The higher tensile strength was obtained in specimens cut at 30 and 45 degrees (Figure 4). Due to the high flowability of SFRSCC, the fibers would have a preferential orientation of 0 degrees (Figure 4). Since fiber pullout tests have shown that a fiber orientation (angle formed between the fiber alignment and the normal to the crack bridged by the fiber) of 30 degrees has assured the highest fiber pullout force, the specimens cut at 30 degrees are expected, in fact, to have the better performance (Cunha, Barros, and Sena-Cruz, 2010).

For the determination of the fracture energy $\left(G_{f}\right)$ of SFRSCC, the same dimensions for the specimens were used. However, in contrast to the previous tensile specimens, the ends of the specimens were not covered with an adhesive, because a notch was applied at the intermediate length of the specimens in order to localize the fracture initiation and propagation at this fracture plane. This notch had a depth of approximately $20 \mathrm{~mm}$ and was made at each smaller side at the intermediate plane of the specimen (Figure 7). In each notch, two metal plates were glued for the installation of the LVDT to measure the crack opening. Another LVDT was attached to the middle of the specimen, with a measuring length of $50 \mathrm{~mm}$, to measure the deformation of the SFRSCC (Figure 8). The test was performed under displacement control at a displacement rate of $1 \mu \mathrm{m} / \mathrm{s}$. The SFRSCC 
Top View
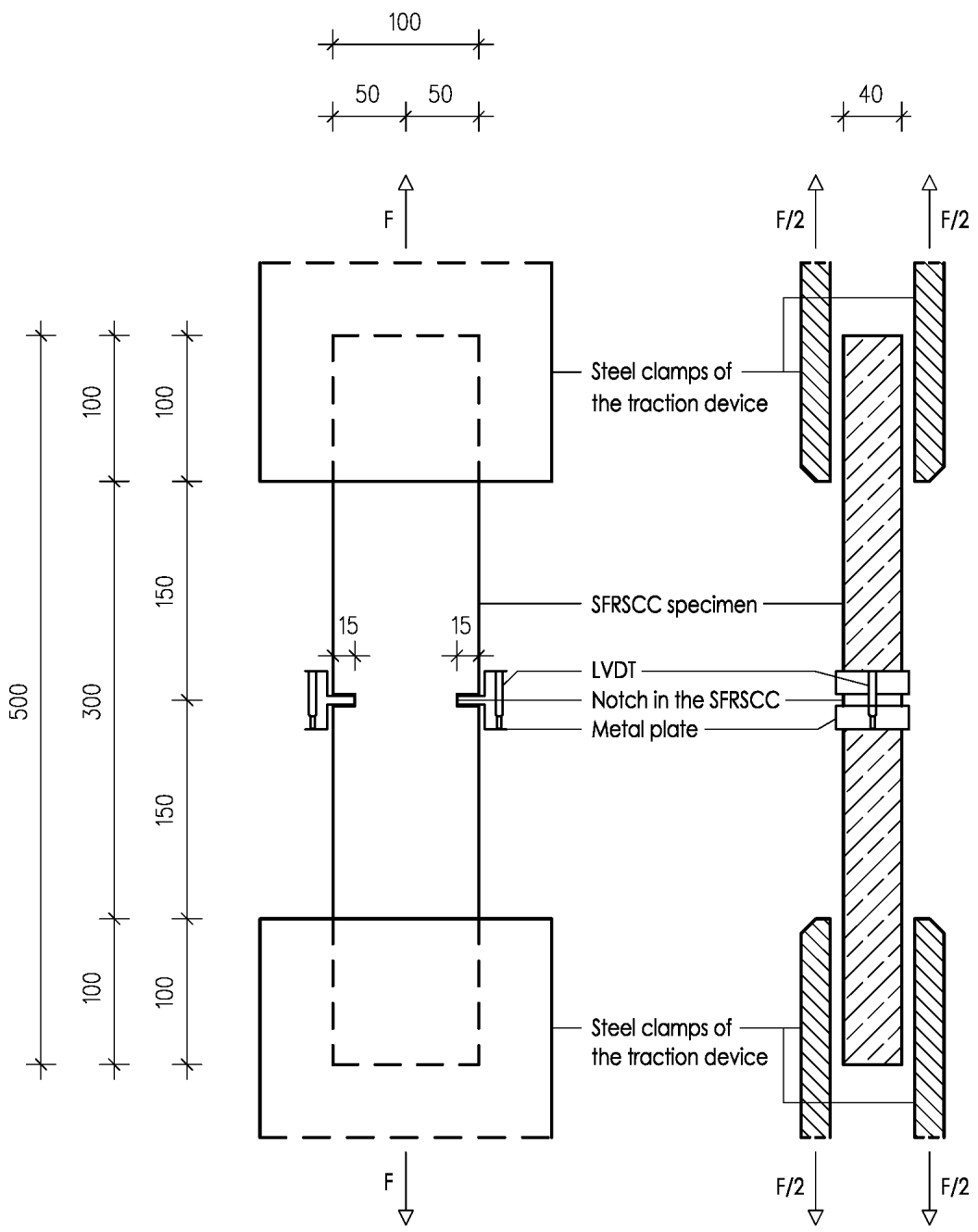

Figure 7. Drawing of the cutting pattern for the determination of the fracture parameters of steel-fibre reinforced self-compacting concrete (SFRSCC) (dimensions in $\mathrm{mm}$ ).

fracture energy was calculated from the stress-crack width response, where the stress is the ratio between the applied force and the net area of the notched plane surface, while the crack width is the average displacement measured in the two LVDTs that were mounted in the two notches. The values for the fracture energy have ranged between $1.43 \mathrm{~N} / \mathrm{mm}$ to $3.83 \mathrm{~N} / \mathrm{mm}$. The average value is indicated in Table 1 .

Due to the non-uniform distribution and orientation of the fibers in the fracture surface, and taking into account that pinned end conditions are applied in the tensile tests, the specimens can be submitted to in-plane and out-of-plane rotations. Therefore, the appropriateness of this test setup to measure the fracture energy of this material can be questionable. Clamped end conditions seem to be more appropriate for measuring the fracture parameters 


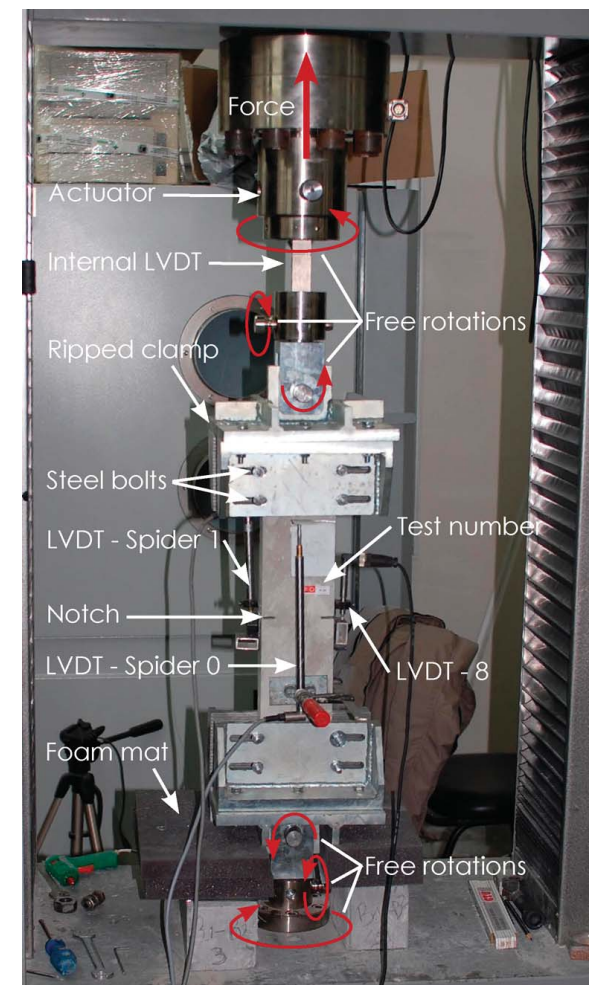

Figure 8. Photograph of a test apparatus for the evaluation of the steel-fibre reinforced self-compacting concrete (SFRSCC) fracture parameters (color figure available online).

of strain softening type materials like the SFRSCC used in the present work, but they could not be materialized with the used equipment.

In addition to the tensile tests, three-point notched beam bending tests with two specimens were also performed according to the RILEM TC-162 recommendations to determine the energy dissipation up to distinct deflection levels (RILEM TC, 2000). The specimens had a length of $600 \mathrm{~mm}$ and a square cross-section of $150 \mathrm{~mm}$ edge. In the centre of the specimens, a notch of approximately $25 \mathrm{~mm}$ depth was sawn at the recommended side of the specimen. The specimens were tested in a three-point bending load configuration, with a distance of $500 \mathrm{~mm}$ between the supports. An LVDT was placed in the centre of the specimen to measure the vertical displacement. The test setup is shown in Figure 9. The load was applied by displacement control at a deflection rate of $1 \mu \mathrm{m} / \mathrm{s}$.

According to RILEM test, a force deflection relationship, F- $\delta$, similar to those depicted in Figure 10 is obtainable. If a clip gauge is mounted at the notch mouth, a force crack mouth opening displacement relationship, $F$-CMOD, can also be recorded. Using these relationships, RILEM TC 162-TDF proposed the evaluation of the load at the limit of proportionality $\left(F_{L}\right)$, the equivalent $\left(f_{e q, 2}\right.$ and $\left.f_{e q, 3}\right)$ and the residual $\left(f_{R, 1}\right.$ and $\left.f_{R, 4}\right)$ flexural tensile strength parameters. $F_{L}$ is the highest value of the load recorded up to a deflection (or CMOD) of $0.05 \mathrm{~mm}$. The parameters $f_{\text {eq, } 2}$ and $f_{\text {eq, } 3}$ are related to the material energy absorption capacity up to a deflection of $\delta_{2}$ and $\delta_{3}\left(\delta_{2}=\delta_{L}+0.65 \mathrm{~mm}\right.$ and $\delta_{3}=\delta_{L}+$ $2.65 \mathrm{~mm}$, where $\delta_{L}$ is the deflection corresponding to $F_{L}$ ) provided by fiber reinforcement 


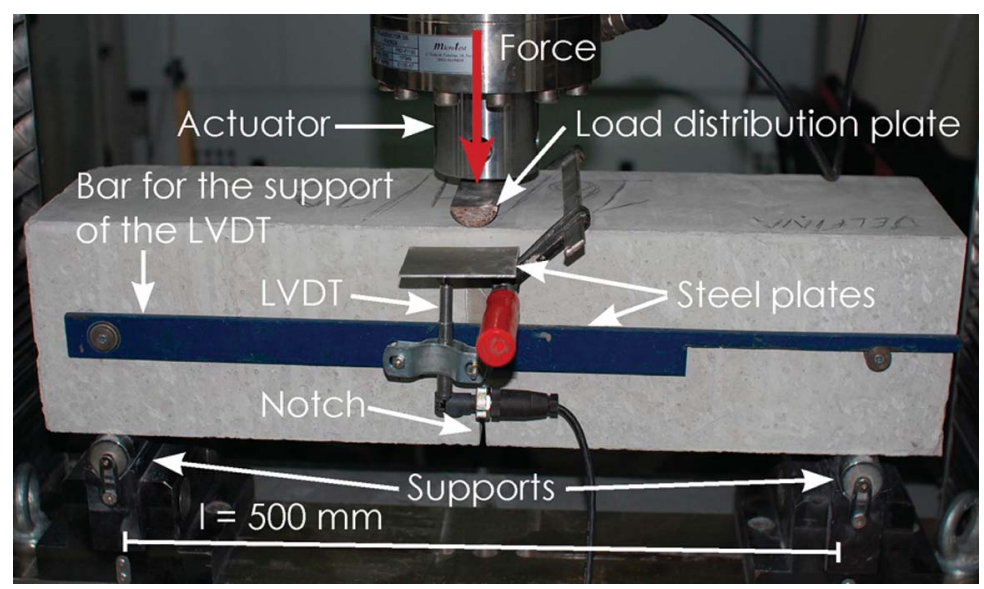

Figure 9. Photograph of the experimental setup of the three-point notched steel-fibre reinforced self-compacting concrete (SFRSCC) beam bending test (color figure available online).

mechanisms ( $D_{B Z, 2}^{f}$ and $D_{B Z, 3}^{f}$ ), as seen in Figure 10. The parcel of the energy due to matrix cracking $\left(D^{b}{ }_{B Z}\right)$ is not considered in the $f_{e q}$ evaluation. The parameters $f_{R, 1}$ and $f_{R, 4}$ are the stresses for the forces $F_{R, 1}$ and $F_{R, 4}$, respectively, at deflection of $\delta_{R, 1}=0.46 \mathrm{~mm}$ and $\delta_{R, 4}=3.0 \mathrm{~mm}$. According to RILEM TC 162-TDF (RILEM TC, 2000), the equivalent and the residual flexural tensile strength parameters are obtained from Equation 3 and Equation 4:

$$
\begin{gathered}
f_{e q, 2}=\frac{3}{2} \frac{D_{B Z, 2}^{f}}{0.50} \frac{L}{b h_{s p}^{2}} ; f_{e q, 3}=\frac{3}{2} \frac{D_{B Z, 3}^{f}}{2.50} \frac{L}{b h_{s p}^{2}} \quad\left[\mathrm{~N} / \mathrm{mm}^{2}\right] \\
f_{R, 1}=\frac{3}{2} \frac{F_{R, 1} L}{b h_{s p}^{2}} ; f_{R, 4}=\frac{3}{2} \frac{F_{R, 4} L}{b h_{s p}^{2}} \quad\left[\mathrm{~N} / \mathrm{mm}^{2}\right]
\end{gathered}
$$

where $b(=150 \mathrm{~mm})$ and $L(=500 \mathrm{~mm})$ are the width and the span of the specimen, and $h_{s p}$ $(=125 \mathrm{~mm})$ is the distance between the tip of the notch and the top of the cross section.

Table 1 includes the average values for the parameters that characterize the postcracking behavior of the SFRSCC. Based on the maximum applied load, an average value of $11.22 \mathrm{MPa}$ was obtained for the flexural tensile strength. Adding $D_{B Z, 3}^{f}$ to $D^{b}{ }_{B Z}$ and dividing by the $A_{\text {lig }}$ (Eq. (2)), an average value of $4.47 \mathrm{~N} / \mathrm{mm}$ was obtained for the energy consumed in the fracture process up to the deflection of $\delta_{3}$. Due to the formation of a failure crack with several branches during the three-point bending test, and the difficulty of determining the area of the fracture surfaces formed during the test, the energy dissipation, determined from the three-point bending tests, was higher than in the axial test, as expected.

\subsection{Bond Behavior}

The bond behavior of the used materials was analyzed by pullout tests according to the DIN EN 1015-12 standard (German Institute for Standardization, 2000). In the 
(a)

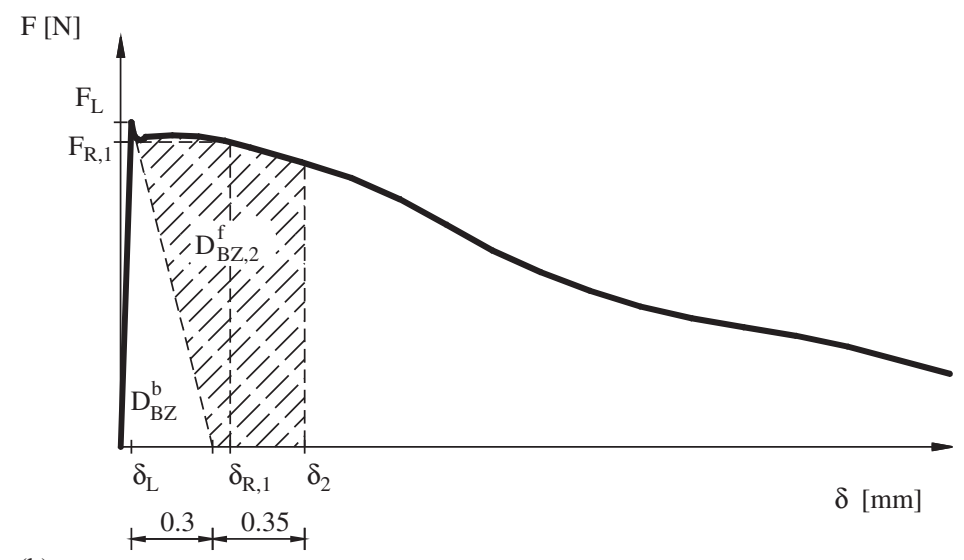

(b)

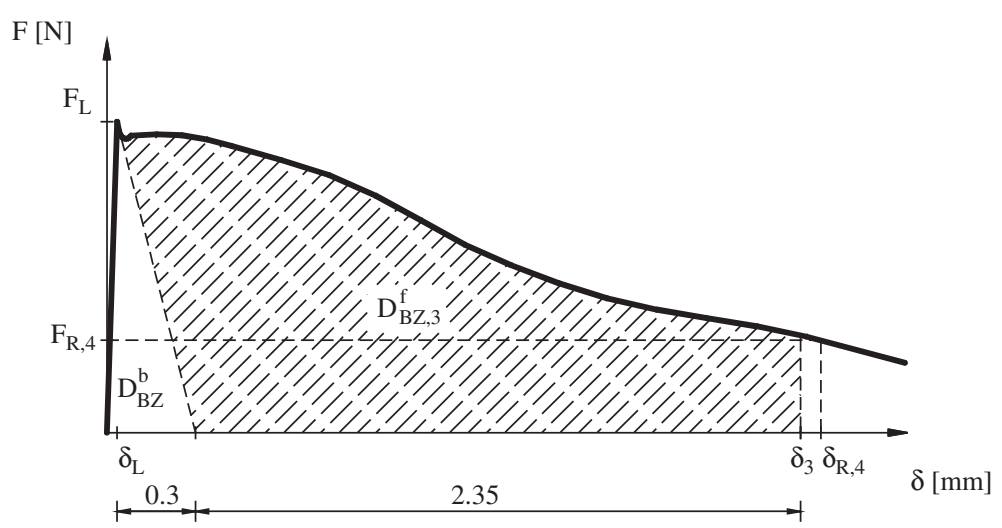

(b)

Figure 10. Evaluation of the flexural tensile strength parameters according to RILEM TC (2000) 162-TDF: a) feq, 2 and fR, 1 ; and b) feq, 3 and fR,4.

tests, the bond performance of a commercial bond agent was also assessed. Four different types of specimens, each composed by two materials, were prepared (type A to D). The four types of specimens differ in the used materials and in the presence or absence of the bond agent in the interface layer. In Figure 11, the different types of specimens are represented. The specimens of type $\mathrm{A}$ and $\mathrm{C}$ were manufactured without the use of the bond agent. In the specimens of type $\mathrm{B}$ and $\mathrm{D}$, the bond agent was applied in the interface layer between the two materials. The types A and B consist of brick and SFRSCC, and were used to determine the bond behavior between these two materials. The specimens of types C and D consist of low strength mortar (LSM) and SFRSCC, and were used to determine the bond strength between LSM and SFRSCC. Before testing, cores with a depth of approximately $32 \mathrm{~mm}$ were drilled in the different specimens. The test was executed with a current pullout-testing device under indirect displacement control at 


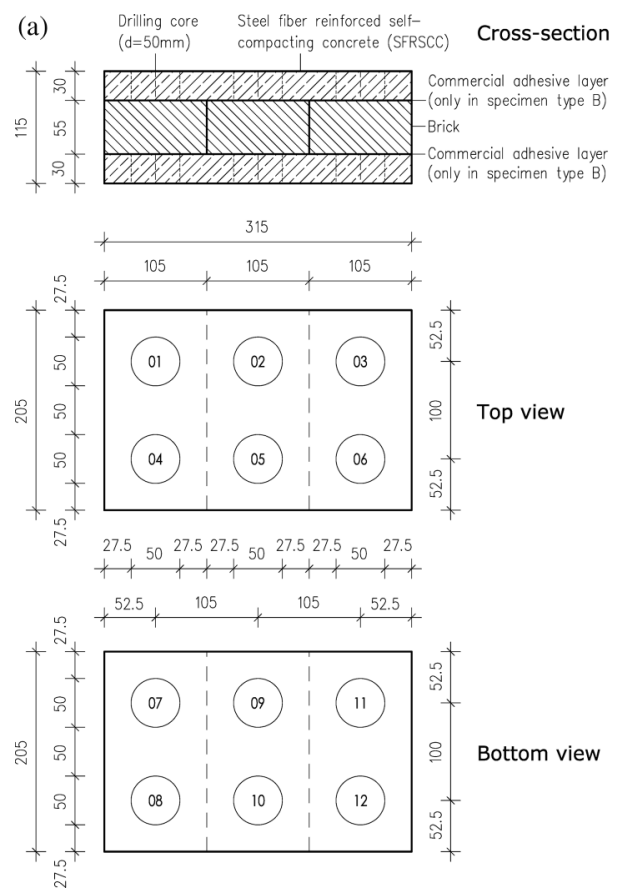

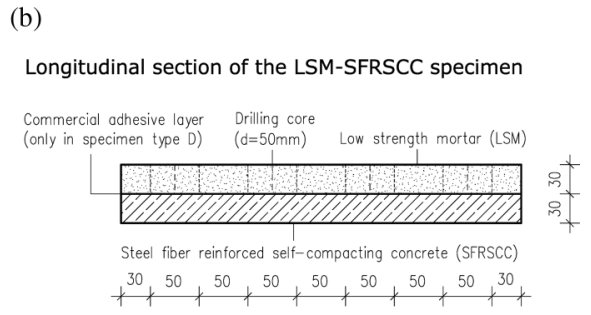

Top view of the LSM-SFRSCC specimen

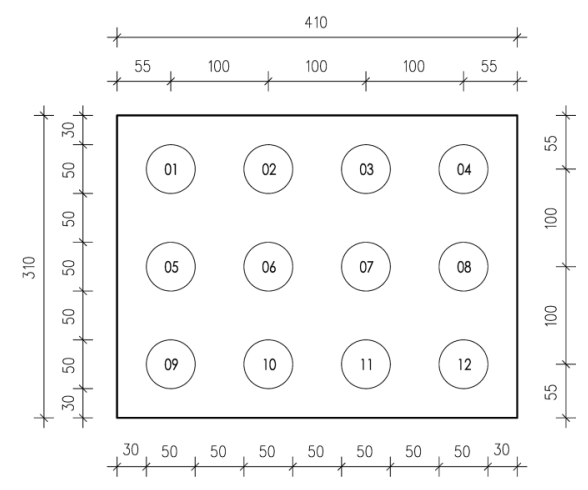

Figure 11. Drawing of the experimental setup for the pullout test: (a) brick-SFRSCC (type A and B); and (b) mortar-steel-fibre reinforced self-compacting concrete (SFRSCC) (type C and D) (dimensions in mm).

(a)

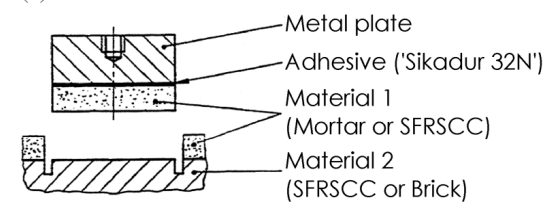

(b)
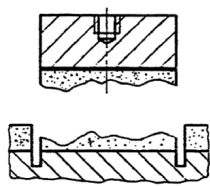

(c)

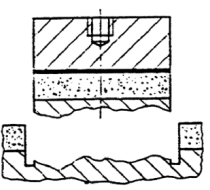

Figure 12. Failure modes occurred in the pullout test program (Häßler, 2010): (a) interface failure (FM1); (b) cohesive failure 1 (FM2); and (c) cohesive failure 2 (FM2).

a velocity of one crank revolution per second. The bond strength $\left(f_{b}\right)$ was calculated by dividing the maximum force $\left(\mathrm{F}_{\mathrm{b} \_ \text {max }}\right)$ by the cross-sectional area of the core $\left(\mathrm{A}_{\text {core }}\right)$. The different failure modes occurred in this pullout test program are illustrated in Figure 12. In general, the bond strength for an interface failure is lower than that for a cohesive failure (cohesive means the fracture propagation through the material). The bond strength from the pullout tests is graphically presented in Figure 13, and the values are included in Table 4. In general, the bond strength between mortar and SFRSCC is much higher than between brick and SFRSCC. The commercial adhesive product had reduced the bond strength for both, the LSM and brick, therefore, its use is not recommended in cement-based materials. 


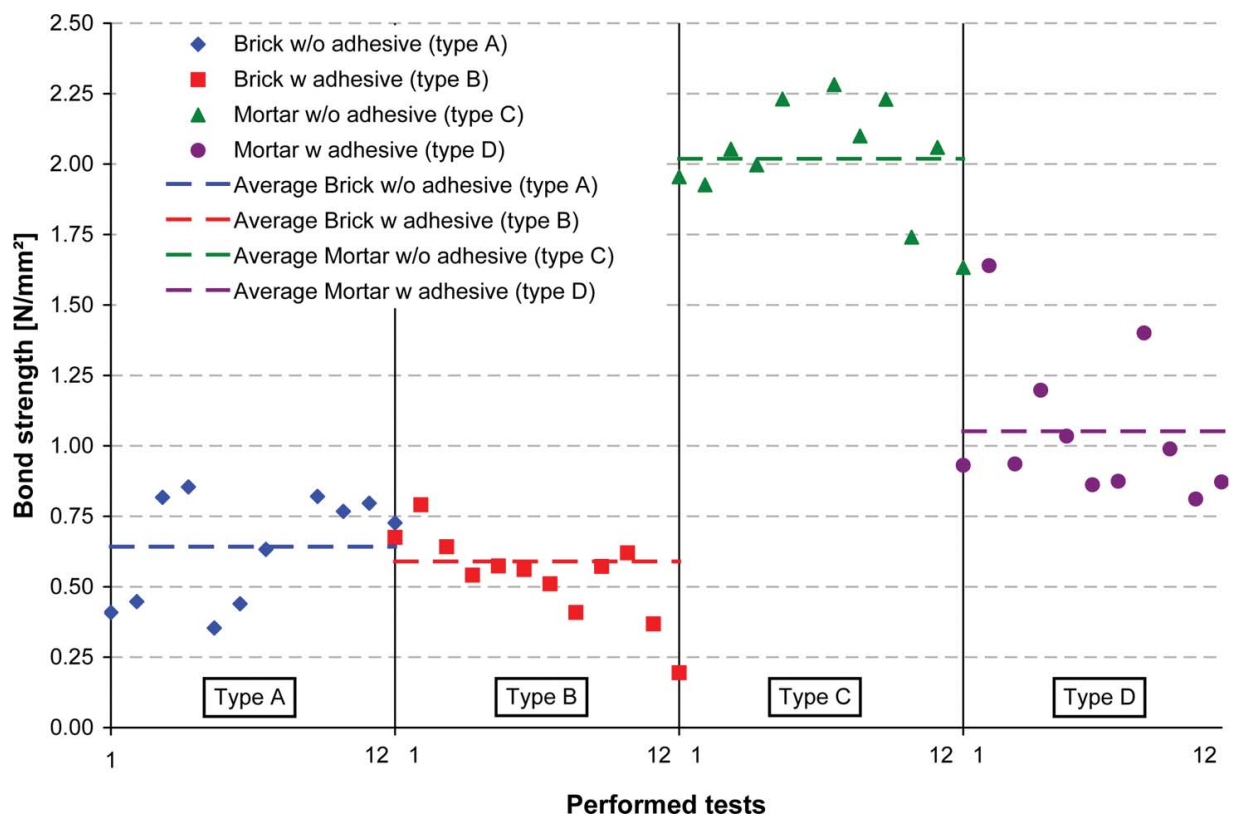

Figure 13. Comparison of the test results from the pullout test (color figure available online).

Table 4. Bond strength and types of failure modes

\begin{tabular}{|c|c|c|c|c|c|c|}
\hline \multirow{2}{*}{$\begin{array}{l}\text { Material } \\
\text { property }\end{array}$} & \multirow[b]{2}{*}{ Symbol } & \multirow[b]{2}{*}{ Unit } & \multicolumn{4}{|c|}{ Specimen } \\
\hline & & & Type A & Type B & Type C & Type D \\
\hline Bond strength & $f_{b}$ & {$\left[\mathrm{~N} / \mathrm{mm}^{2}\right]$} & $0.64(0.19)$ & $0.59(0.10)$ & $2.02(0.20)$ & $1.05(0.25)$ \\
\hline $\begin{array}{l}\text { Failure mode } \\
\qquad(\mathrm{FM})\end{array}$ & - & - & $\begin{array}{l}\text { Cohesive failure } \\
\text { (FM1) }\end{array}$ & $\begin{array}{l}\text { Cohesive failure } \\
\text { (FM1) }\end{array}$ & $\begin{array}{l}\text { Cohesive failure } \\
\text { (FM1) }\end{array}$ & $\begin{array}{l}\text { Cohesive (FM1)/ } \\
\text { Interface failure } \\
\text { (FM2) }\end{array}$ \\
\hline
\end{tabular}

These values in parentheses (...) refer to the standard deviation of the tests.

\section{ASSESSMENT OF THE FLEXURAL STRENGTHENING EFFECTIVENESS OF THE PROPOSED TECHNIQUE}

\subsection{Introduction}

To determine the potentialities of a thin layer of SFRSCC to increase the flexural load-carrying capacity of handmade brick-based masonry structural elements failing in bending, straight beams composed of handmade bricks bonded by a low strength mortar (LSM) and covered by a thin layer of SFRSCC were used. Since the maximum dimension of the aggregates $\left(D_{\max }\right)$ in the mix composition of SFRSCC was approximately $10 \mathrm{~mm}$ and fiber length is $35 \mathrm{~mm}$, to assure an homogeneous distribution of the aggregates in the layer and to avoid segregation of fibers it is recommended that the thickness of the SFRSCC layer is larger than 3 times $\mathrm{D}_{\max }$ and larger than the fiber length. Taking the results from the direct tensile tests and performing preliminary numerical simulations with a cross section layer model it was verified that a significant increase in both the flexural resistance and 
stiffness could be achieved with a SFRSCC layer of $30 \mathrm{~mm}$ thick. Furthermore, to be aesthetically sustainable and to minimize the increase of the permanent load derived from this strengthening technique, the minimum acceptable thickness layer for the SFRSCC was adopted. Therefore, a thickness of $30 \mathrm{~mm}$ was selected for the SFRSCC layer.

The SFRSCC layer was applied on top of the brick-low strength mortar beams. The beams with a span of $750 \mathrm{~mm}$, a width of $205 \mathrm{~mm}$ and a total height of $135 \mathrm{~mm}$ were tested in a four-point bending load configuration. To apply tensile stresses in the SFRSCC layer, the beam prototypes were tested with the SFRSCC layer in the bottom. To assess the influence in terms of flexural strengthening effectiveness by replacing part of the LSM in the joints by SFRSCC, a series of prototypes with a LSM depth of $30 \mathrm{~mm}$ substituted by SFRSCC was also tested.

\subsection{Prototypes}

Two types of composite beams were manufactured as represented in Figure 14. For each type, three beams were produced. The two different types differ only in the depth of mortar in the joints between the bricks. In type I (Specimens T_01, T_02, T_03), the mortar was applied in the joints over the entire height of the brick. In type II (Specimen T_31, T_32, T_33), the mortar was inserted with $30 \mathrm{~mm}$ less height, in order that a $30 \mathrm{~mm}$ thick layer of SFRSCC can be applied at the bottom of the joint, resulting a ribbed type SFRSCC "slab". The orientation of the ribs provides the lowest contribution for the flexural capacity of these beams, since they are orthogonal to the principal tensile stresses. A larger effectiveness of these ribs is expected in cases of structural elements with joint grid pattern and working like slabs or shells.

From the available handmade brick elements, the best ones were selected by visual inspection. Bricks with cracks, flaking or high water content were rejected. Each specimen

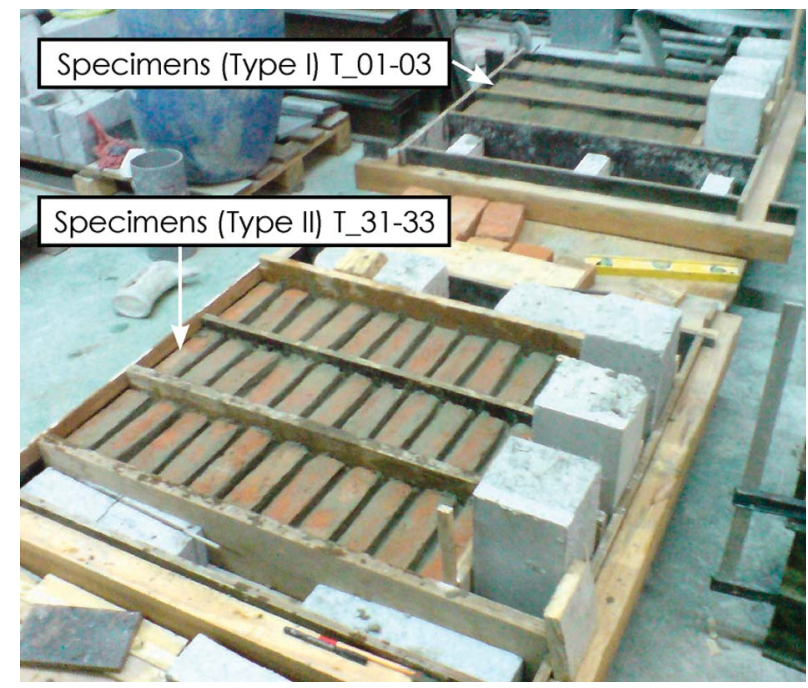

Figure 14. Photograph of the composite beam prototypes after the casting of the mortar (color figure available online). 
is formed by eleven bricks. Afterwards, the bricks were laid within the previously manufactured formwork and aligned. Due to the irregular surface of the bricks, the width of the joints varied between 10 to $20 \mathrm{~mm}$.

After the mixing, the viscous mortar was inserted into the joints and compacted by hand and with the help of a trowel. Due to the high water content of the mortar, the dry and porous brick surfaces were not pre-wetted. The compliance with the $30 \mathrm{~mm}$ deep cavity in the joints of the specimens type II was checked by a ruler and, if necessary, the depth was adjusted accordingly. Afterwards, to prevent the premature drying of the mortar surface, the entire specimen was moistened with water by using a brush. After 1 day of curing, the already solid mortar was cleaned from dust and loose mortar residues. Then the adhesive and afterwards the SFRSCC were applied to the specimens. The mixture indicated in Table 5 for the adhesive was used. After casting the SFRSCC, its outer surface was uniformly smoothed with a wooden board, so that a SFRSCC thickness of approximately $30 \mathrm{~mm}$ was almost guaranteed (apart the irregularities of the top surface of the bricks). After casting the SFRSCC, the composite beams were maintained for 24 hours in the formwork and then de-moulded. The specimens were maintained for another 15 days in the laboratory under normal room temperature until the testing. The commercial bond adhesive was used in the beam prototypes because the results of the bond tests were obtained only after the construction of these prototypes.

\subsection{Test Setup and Monitoring System}

The six composite beams were tested in a four-point-bending load configuration (Figure 15). The distance between the roller supports was $750 \mathrm{~mm}$. The composite beams were laid on the supports with the SFRSCC layer on the bottom side to evaluate the strengthening contribution of the SFRSCC when being subjected to tension. The force from the actuator was applied to the beams by using a double-T-steel profile and two halfroller bearings. The half-roller bearings were located $250 \mathrm{~mm}$ from each support. Below each half-roller bearing, a load distribution plate was inserted to reduce stress concentration. This insertion was also done to ensure that the load was equally distributed between the mortar joints and the brick elements.

To measure the vertical deflection of a beam, five LVDTs were placed at the longitudinal side, supported on a metal bar that avoids the extraneous readouts from the settlements at the supports of the beam and the deformability of the reaction frame (Figure 15). The test was performed under displacement control, taking the signal of the LVDT in the middle of the beam for this purpose. The velocity of the test was $3 \mu \mathrm{m} / \mathrm{s}$. The test was stopped after a final displacement of 9 to $10 \mathrm{~mm}$, or when the measured force reached a value less than $0.3 \mathrm{kN}$ after the peak load. A load cell of $50 \mathrm{kN}$ maximum capacity and an accuracy of $0.05 \%$ was attached to the actuator to measure the applied force.

Table 5. Recommendation of the manufacturer for the production of the adhesive layer

\begin{tabular}{lcccc}
\hline Application type & Layer thickness & Bond agent : Water & Cement : Mortar & $\begin{array}{c}\text { Consumption of the } \\
\text { adhesive }\left[1 / \mathrm{m}^{2}\right]\end{array}$ \\
\hline Adhesive layer & $0-10 \mathrm{~mm}$ & $1: 1$ & $1: 2$ & $0.01 \mathrm{~kg} / \mathrm{mm}$ (thickness) \\
\hline
\end{tabular}



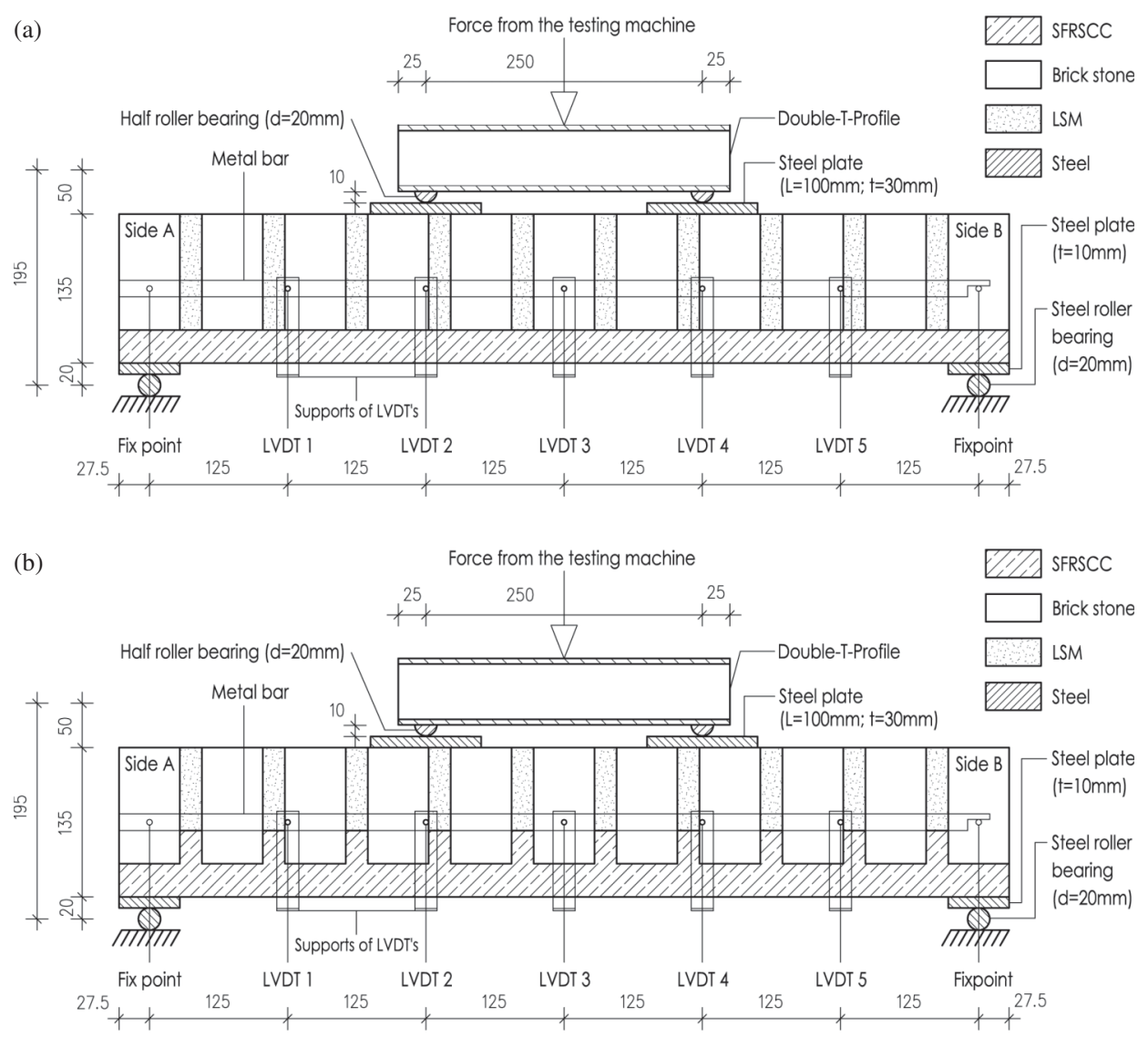

Figure 15. Drawing of the experimental setup of the four-point bending test for the composite beam: (a) beam prototype T_01-03; and (b) beam prototype T_31-33.

\subsection{Results and Discussion}

To distinguish the tested specimens, the designation ' $\mathrm{T} \_\mathrm{XY}$ ' was used, where ' $\mathrm{T}$ ' stands for test, the first variable ' $\mathrm{X}$ ' indicates the depth, in cm, of the SFRSCC into the mortar joints, and the second variable ' $\mathrm{Y}$ ' refers to the index number of the test. For instance, T_31 is the first prototype with $30 \mathrm{~mm}$ of LSM replaced by SFRSCC in the joints. Four of the six tested specimens (T_02, T_03, T_31, T_32) were failed by a single vertical crack near one of the load application points. Two examples of this failure mechanism are shown in Figure 16 and Figure 17. The specimens T_01 and T_33 were failed by the formation of several cracks between the two load application points (Figure 18). Apart from this classification, the failures can be distinguished by the pattern of the failure crack. In the specimens T_02 and T_03, the crack started in the SFRSCC layer and continued in the interface between the brick and the mortar. This type of failure is presented in Figure 16. In the second type of failure pattern (Figure 17), the crack also started in the SFRSCC but continued, first in the brick, and then proceeded in the brick-LSM interface. This distinct crack propagation profile contributed for a much higher load carrying capacity in the specimens with the failure crack crossing a brick. This indicates that the tensile strength of 

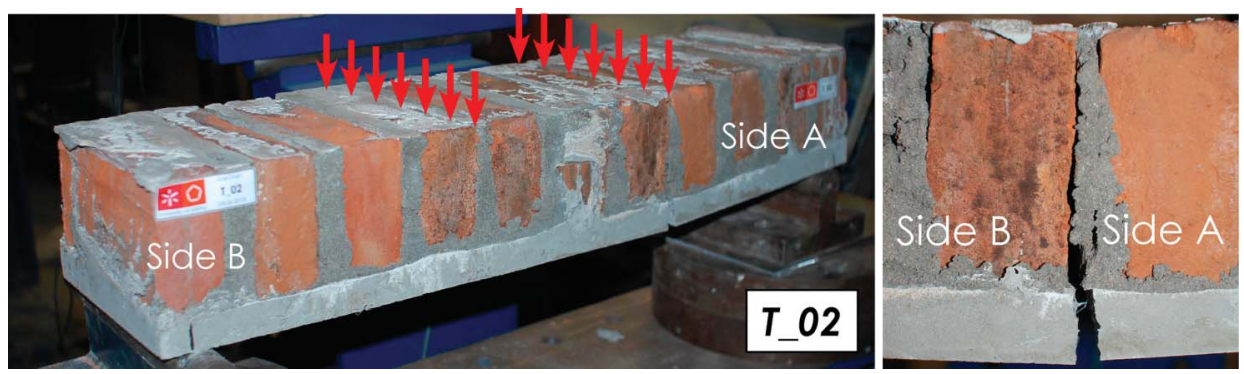

Figure 16. Photographs of the crack in the interface layer between the mortar and the brick in the T_02 beam (color figure available online).
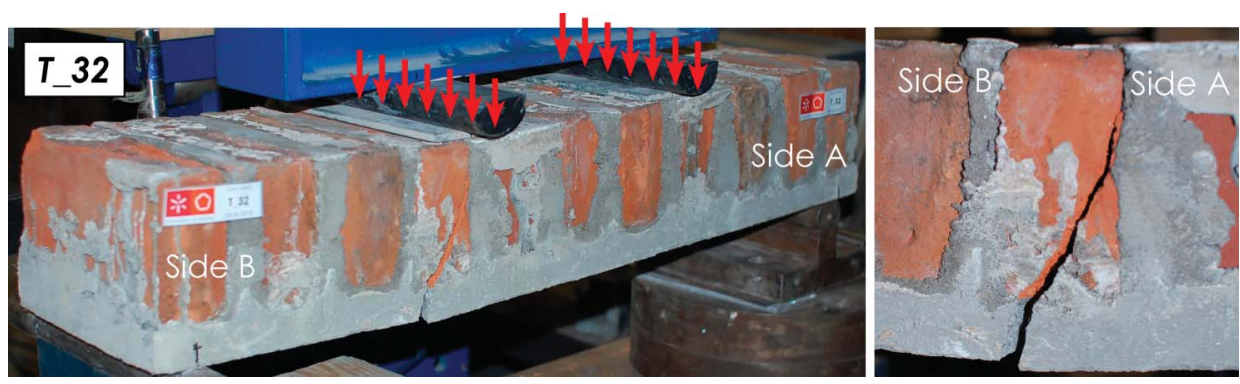

Figure 17. Photographs of the crack crossing the brick and following the interface layer between mortar and brick in the T_32 beam (color figure available online).

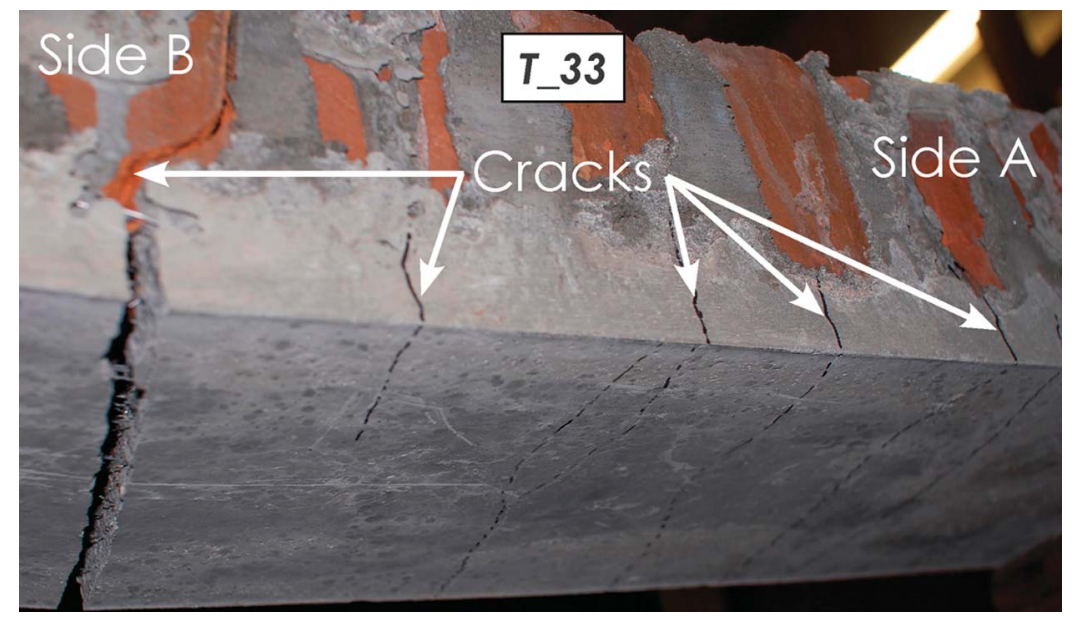

Figure 18. Photographs of the formation of several cracks during the four-point bending test of the composite beam T_33 (color figure available online).

the brick is higher than the bond strength between the brick and the low strength mortar. One reason for the low bond strength between the mortar and the brick can be related to the manufacturing of the beam prototypes, due to the difficult conditions for the compaction of the LSM into the joints. The deficiency in terms of brick-LSM bond conditions increases 
from top to bottom (it should be remembered that the casting and the loading have opposite directions), which favor the redirection of the crack propagation towards the brick-LSM interface during the loading process. Furthermore, due to the relative high tensile strength of the mortar, cracks never progressed through the mortar joint, which also contributed to the localization of the failure crack at the brick-LSM interface. Since the typical failure mode represented in Figure 16 did not occur in the T_3i specimens (with $i=1$ to 3), the relatively high bond strength of the brick-SFRSCC interface in the zone of the joint where SFRSCC was introduced has favored the propagation of the crack through the brick, resulting in a significant increase of the stiffness and load carrying capacity of the beam (Figure 19).

Due to these distinct types of crack patterns, Figure 19 shows that the force-deflection relationship registered in the tested specimens is quite distinct, not only in terms of stiffness, but also in load carrying capacity and ductility. The presence of the SFRSCC ribs has increased the flexural stiffness of the specimens. Apart the T_01 specimen, they have also increased the load carrying capacity of the specimens. The maximum load varied between $4.74 \mathrm{kN}$ and $13.96 \mathrm{kN}$, and these maximum loads occurred for a vertical deflection of 1 to $2 \mathrm{~mm}$. After peak load, all the specimens presented a deflection-softening phase. The differences between the curves can also be explained by the different thickness of the SFRSCC layer $(26-31 \mathrm{~mm})$ and the number of steel fibers in the failure fracture surface $\left(\mathrm{N}_{\mathrm{f}}{ }^{\mathrm{eff}}=\right.$ 7-60 fibers). The criteria proposed by Robins, Austin, and Jones (2002) was followed for the evaluation of the number of fibers assumed as contributing effectively for the flexural resistance of the beam. According to these authors, a hooked ends steel fiber is effective in terms of fiber reinforcement mechanisms it can provide to a cement based material, if its embedded length is larger than $5 \mathrm{~mm}$, which is usually the length of the hooked ends of steel fibers available in the market, and used in the present work. The relationship between the number of steel fibers in the fracture surface of the failure crack and the maximum applied force, $F_{\max }$, is shown in Figure 20. From this figure it can be observed a tendency

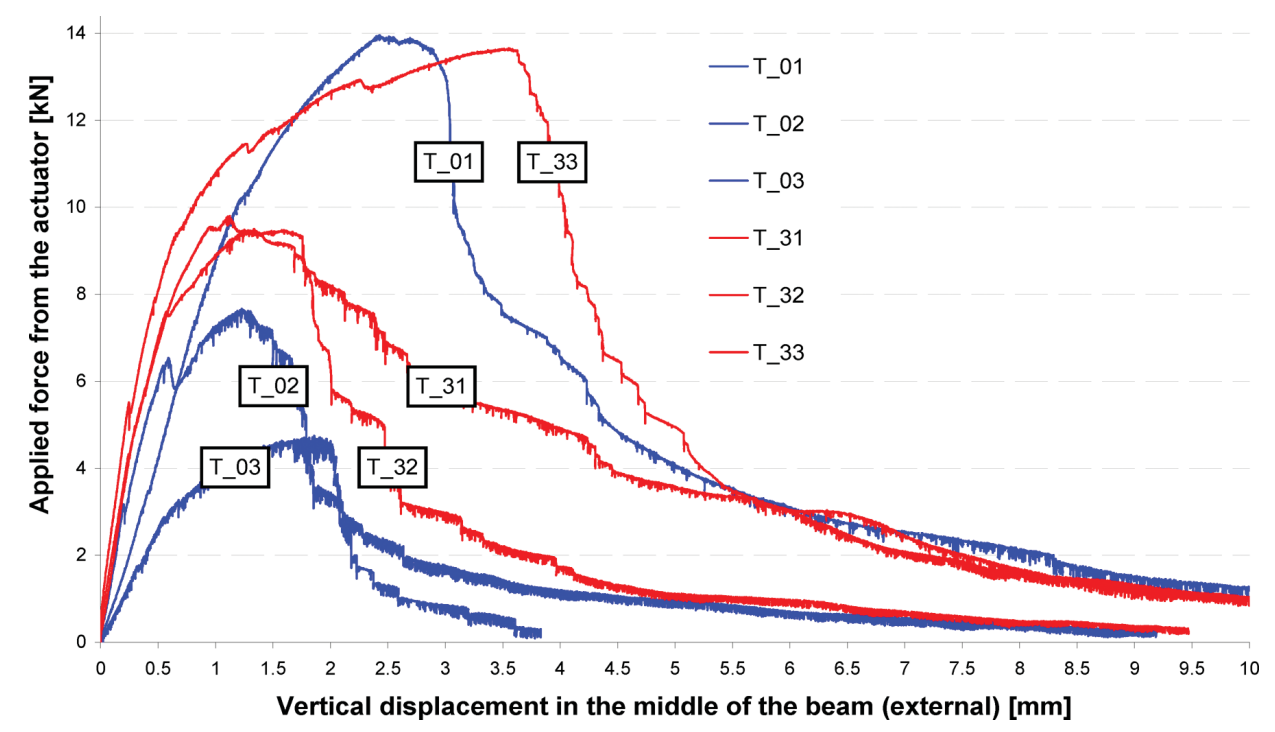

Figure 19. Force-displacement diagram of the tested composite specimens (color figure available online). 


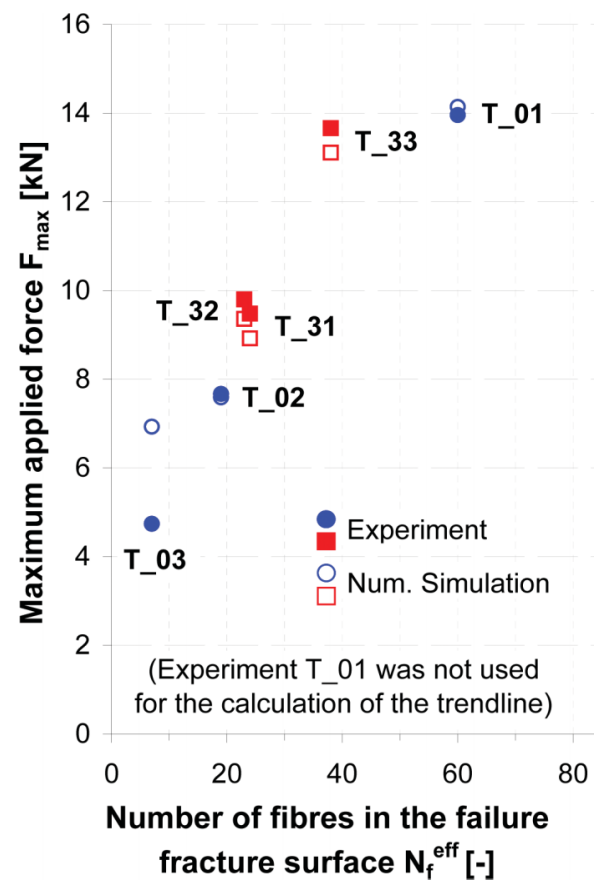

Figure 20. Relationship between the number of steel fibers in the fracture surface and the maximum applied load (color figure available online).

for the increase of $F_{\max }$ with the number of fibers in the fracture surface of the failure crack. The maximum number of fibers in the failure crack of the T_01 and T_33 specimens justifies the highest number of cracks occurred in these specimens (Figure 18) and, consequently, the maximum load registered in these prototypes.

\section{PREDICTION OF THE MAXIMUM LOAD}

To predict the flexural capacity of these specimens, a cross-section layer model that was implemented into DOCROS computer program was used (Basto and Barros, 2008). This model assumes that a plane section remains plane after deformation and bond between materials is perfect. The section is divided in horizontal layers, and the thickness and width of each layer is user-defined and depend on the cross-section geometry. DOCROS can analyze sections of irregular shape and size, composed of different types of materials subjected to an axial force and variable curvature. Composite layers are used when more than one material exist at same depth of the cross section. Each layer can have an initial non-null stress in order to simulate a pre-stress effect. The software can also analyze sections that have layers with distinct construction phases, such as in the case of retrofitting, where strengthening materials are active in later phases. DOCROS has a wide database of constitutive laws for the simulation of monotonic and cyclic behavior of cement based materials, polymer based materials and steel bars.

Due to the distinct paths of the failure crack propagation, the following three paths can resume the three types of failure modes registered experimentally: a) SFRSCC 

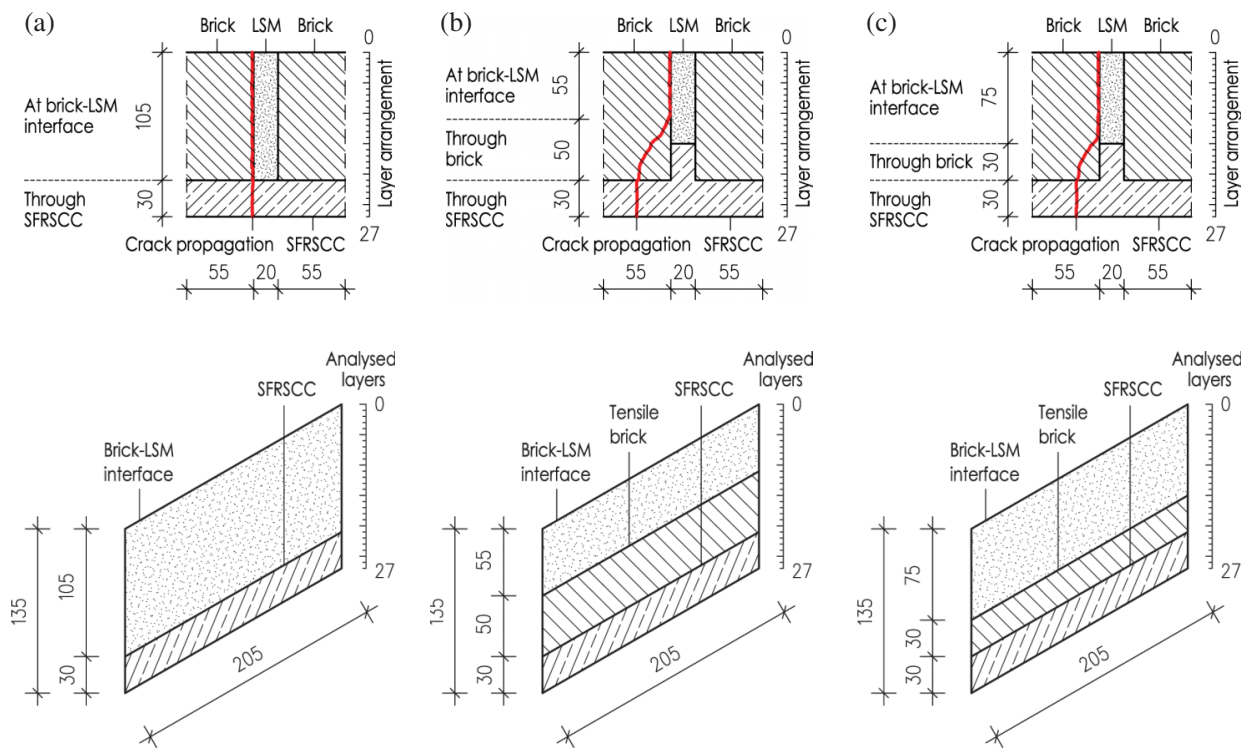

Figure 21. Drawing of the layer discretization for the different failure modes (longitudinal view and cross section): a) SFRSCC layer/brick-LSM interface; and b) SFRSCC layer/tensile brick (in $50 \mathrm{~mm}$ )/brick-LSM interface; c) SFRSCC layer/tensile brick (in $30 \mathrm{~mm}$ )/brick-LSM interface (color figure available online).

layer/brick-LSM interface (Figure 21a); b) SFRSCC layer/tensile brick (in $50 \mathrm{~mm}$ )/brickLSM interface (Figure 21b); c) SFRSCC layer/tensile brick (in $30 \mathrm{~mm}$ )/brick-LSM interface (Figure 21c). For the paths shown in Figure 21b and 21c, it was assumed that failure crack progressed in almost one-half and one-third height of the brick, respectively. To obtain the moment-curvature relationship for these three types of cross-sections, the properties indicated in Table 1 and Table 6 were used to define the constitutive models that characterize the behavior of the constituent materials (see also Figure 22a-c). To describe the material behavior in compression for SFRSCC, brick and LSM the stress-strain diagram represented in Figure 22a was used. The stress-strain diagram shown in Figure 22b was used to simulate the tensile behavior up to the tensile strength of SFRSCC, brick, and LSM. Finally, the trilinear stress-crack width diagram represented in Figure 22c was

Table 6. Material parameters for the simulation of the post-cracking behavior of steel-fibre reinforced selfcompacting concrete (SFRSCC) and results for the maximum load carrying capacity in the experiment and in the numerical simulation

\begin{tabular}{|c|c|c|c|c|c|c|c|c|c|c|c|}
\hline Specimen & $\begin{array}{c}\mathrm{N}_{\mathrm{f}}{ }^{\mathrm{eff}} \\
{[-]}\end{array}$ & $\begin{array}{c}\sigma_{0.3 \mathrm{~mm}} \\
{\left[\mathrm{~N} / \mathrm{mm}^{2}\right]}\end{array}$ & $\begin{array}{c}\sigma_{1 \mathrm{~mm}} \\
{\left[\mathrm{~N} / \mathrm{mm}^{2}\right]}\end{array}$ & $\begin{array}{c}\mathrm{G}_{\mathrm{f}} \\
{\left[\mathrm{N} / \mathrm{mm}^{2}\right]}\end{array}$ & $\begin{array}{c}\mathrm{f}_{\mathrm{tm}} \\
{\left[\mathrm{N} / \mathrm{mm}^{2}\right]}\end{array}$ & $\begin{array}{c}\omega_{0.30 \mathrm{~mm}} \\
{[\mathrm{~mm}]}\end{array}$ & $\begin{array}{l}\omega_{1 \mathrm{~mm}} \\
{[\mathrm{~mm}]}\end{array}$ & $\begin{array}{l}\omega_{\lim } \\
{[\mathrm{mm}]}\end{array}$ & $\begin{array}{c}\mathrm{F}_{\max \_\exp } \\
{[\mathrm{kN}]}\end{array}$ & $\begin{array}{c}\mathrm{F}_{\max \_n u m} \\
{[\mathrm{kN}]}\end{array}$ & $\begin{array}{l}\text { Failure } \\
\text { Mode }\end{array}$ \\
\hline T_01 & 60 & 1.90 & 2.42 & 5.406 & 3.01 & 0.30 & 1.00 & 3.61 & 13.96 & 14.14 & b) \\
\hline T_02 & 19 & 0.59 & 0.47 & 1.773 & 3.01 & 0.30 & 1.00 & 4.69 & 7.67 & 7.59 & a) \\
\hline T_03 & 7 & 0.20 & 0.00 & 0.710 & 3.01 & 0.30 & $\omega_{\lim }$ & 2.57 & 4.74 & 6.93 & a) \\
\hline T_31 & 24 & 0.75 & 0.71 & 2.216 & 3.01 & 0.30 & 1.00 & 4.24 & 9.48 & 8.92 & c) \\
\hline T_32 & 23 & 0.72 & 0.66 & 2.128 & 3.01 & 0.30 & 1.00 & 4.30 & 8.80 & 9.36 & b) \\
\hline T_33 & 38 & 1.20 & 1.37 & 3.457 & 3.01 & 0.30 & 1.00 & 3.81 & 13.66 & 13.11 & c) \\
\hline
\end{tabular}



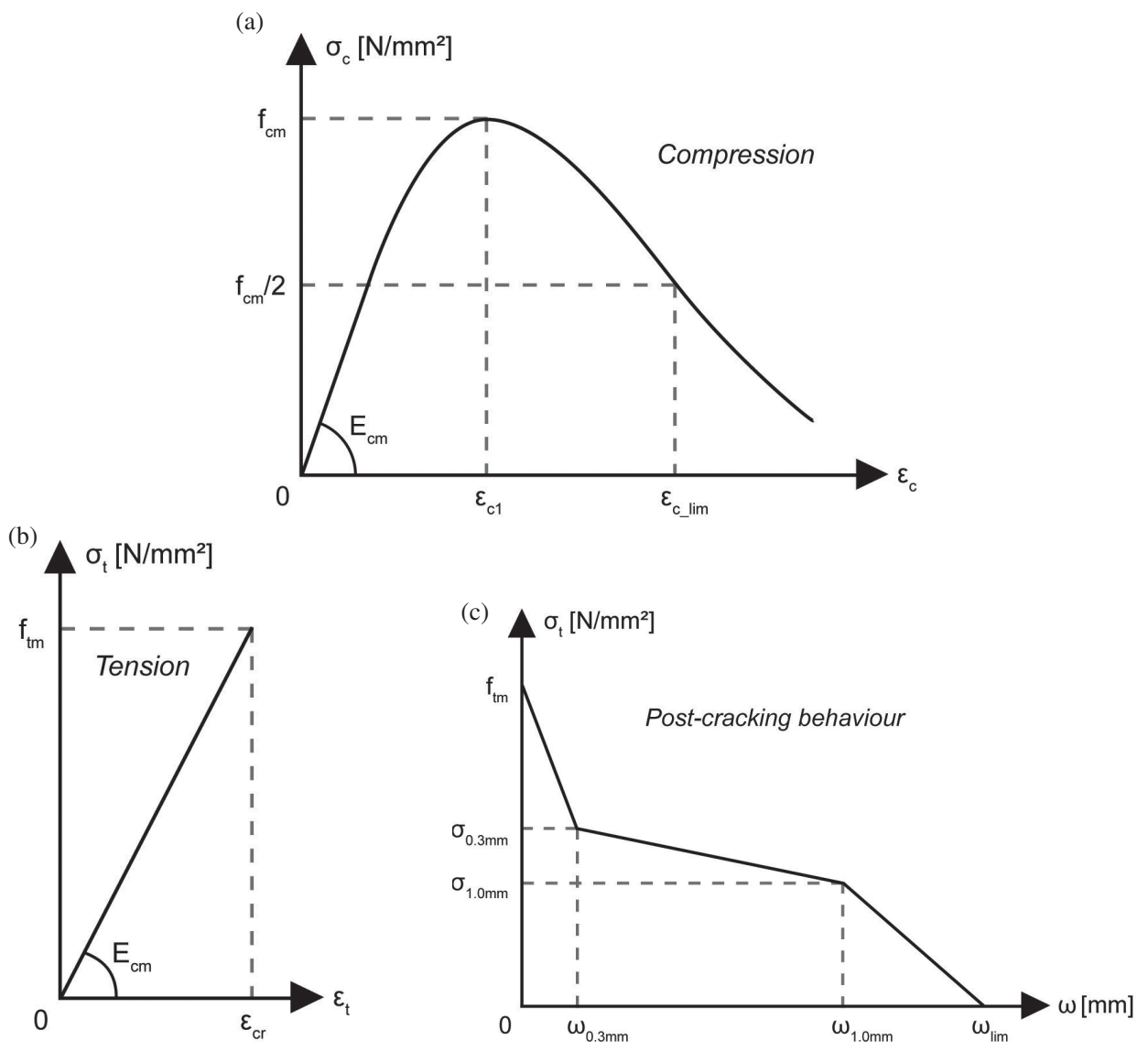

Figure 22. Constitutive laws to simulate the: a) compression behavior for SFRSCC, brick and LSM; b) tensile behavior for SFRSCC, brick and LSM; and c) post-cracking tensile behavior of SFRSCC.

adopted to simulate the post-cracking tensile behavior of SFRSCC, while null residual tensile strength was assumed for bricks and LSM. The values of the parameters that define the post-cracking residual strength of the SFRSCC were determined for each specimen taking into account the number of effective fibers in the failure fracture surface (Figure 22) and the results obtained by Cunha et al. (2010), (Figure 23), performing the appropriate extrapolation. The number of effective fibers in the failure fracture surface was also used to obtain the corresponding fracture energy of each specimen. Therefore, a linear interpolation between the fracture energy of plain concrete $\left(\mathrm{N}_{\text {eff }}^{\mathrm{f}}=0 ; \mathrm{G}_{\mathrm{f}}=0.09 \mathrm{~N} / \mathrm{mm}\right)$ and the average value determined in the experiments $\left(\mathrm{N}_{\text {eff }}^{\mathrm{f}}=26.5 ; \mathrm{G}_{\mathrm{f}}=2.439 \mathrm{~N} / \mathrm{mm}\right)$ was used. Based on the fracture energy, which is equal to the area under the stress-crack width diagram, the ultimate crack width opening $\left(\omega_{\text {lim }}\right)$ was calculated (Table 6).

Figure 21 shows the layered discretization of the three types of cross section. Taking the maximum moment determined from the moment-curvature relationships, the maximum loads determined numerically are compared in Table 6 with the corresponding ones measured experimentally. The obtained good prediction indicates that this strategy is suitable to determine the flexural capacity of the cross section of handmade brick-based masonry 

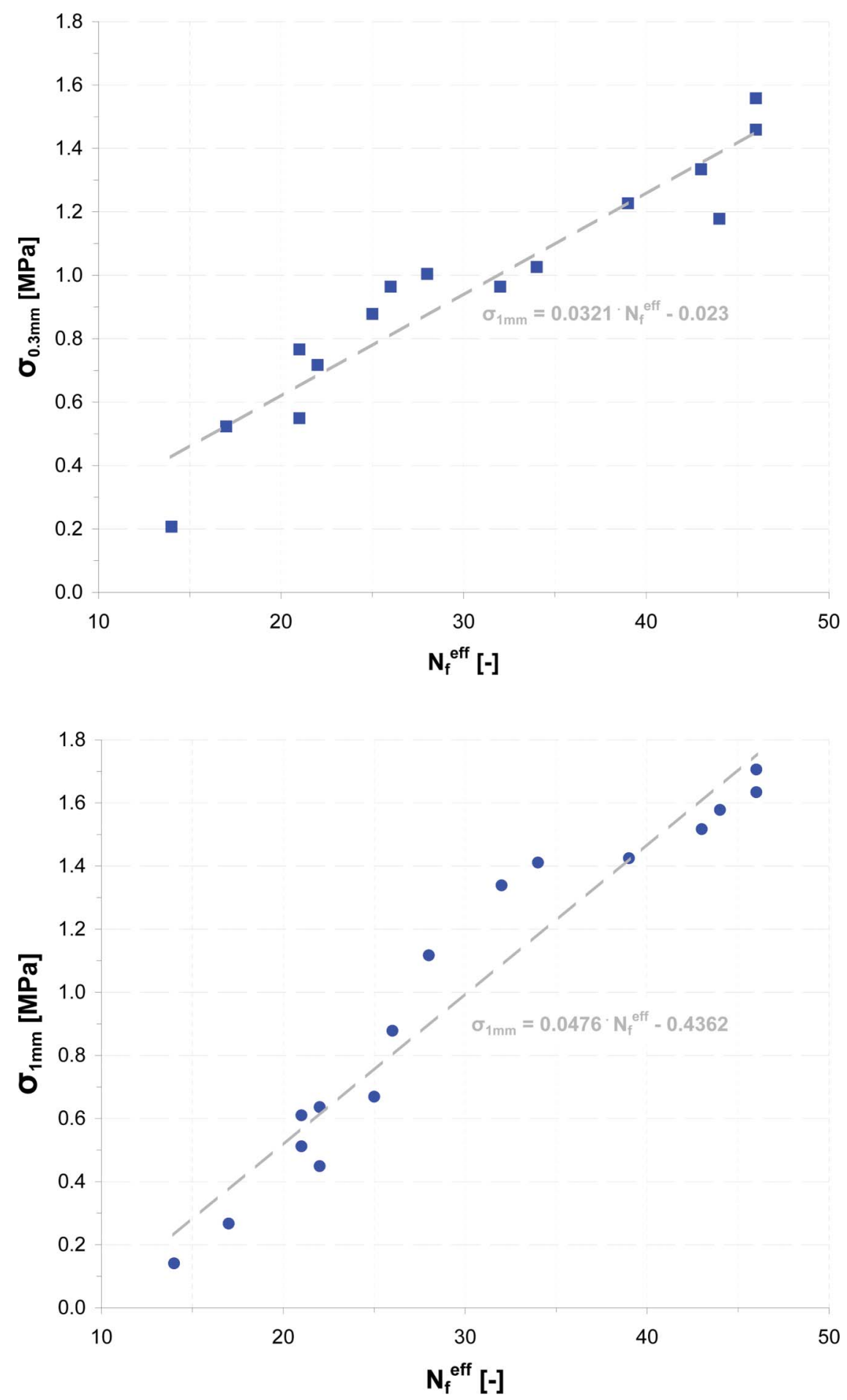

Figure 23. The influence of the effective number of fibers in the post-cracking residual tensile strength at: a) $0.3 \mathrm{~mm}$; and b) $1.0 \mathrm{~mm}$ (Cunha et al. 2010) (color figure available online). 
structural elements failing in bending, from which their load carrying capacity can be estimated using complementary design approaches (Palácio, Lourenço, and Barros, 2003).

Since the number of fibers in the fracture surface cannot be known a prior (in the design phase), the design approach recommended by CEB-FIP Model code (Comité EuroInternational du Béton, 2010) should be followed, where the constitutive law that simulates the tensile behavior of a FRC is defined by using the concepts of residual flexural tensile strength parameters, already introduced. Due to the high dispersion of the number of fibers registered in the tested beam prototypes, and since the thickness of the SFRSCC should be not increased, it is recommended to use a hooked ends steel fiber with a length of $30 \mathrm{~mm}$ and an aspect ratio $\left(l_{f} / d_{f}\right)$ near 80 , since this leads to a much higher number of fibers per unit volume of concrete. To avoid high penalization when obtaining design values for the residual flexural tensile strength parameters from the characteristic ones, it is recommended to execute series of 9 to 12 tests.

\section{CONCLUSIONS}

In this work, the effectiveness of a strategy based on the use of a thin layer of steel fiber reinforced self-compacting concrete (SFRSCC) for the flexural strengthening of handmade brick-based masonry structural elements failing in bending is assessed by performing an experimental program. In this experimental program, the relevant properties of SFRSCC, bricks, and low strength mortar (LSM) were characterized, having been done particular attention to the evaluation of the SFRSCC tensile behavior and brick-SFRSCC and LSM-SFRSCC bond behavior. From the obtained results, it can be concluded that the use of a $30 \mathrm{~mm}$ thick layer of SFRSCC in the tension zone of the composite beam, compared to a pure brick-mortar beam, has increased the flexural load-carrying capacity by approximately 120 percent. The replacement of part of the mortar existing in the joints by SFRSCC had beneficial effects in terms of flexural stiffness and load carrying capacity, and has contributed to the development of a relatively diffuse crack pattern in the SFRSCC layer. A strengthening technique that favors the propagation of the failure cracks through brick elements is able to increase the load carrying capacity of this type of structures. The benefits of replacing part of the LSM in the joints by SFRSCC can be even more significant in slab and shell masonry type structures where the SFRSCC layer ribbed grid offers resistance to the three moment components installed in this type of structures. A relatively high scatter was obtained for the increase of the flexural load capacity provided by the proposed strengthening technique, derived, mainly, from the quite large dispersion on the number of effective fibers crossing the fracture surface registered in the tested beam prototypes.

To decrease this scatter it is recommended the use of steel fibers of smaller length $(30 \mathrm{~mm})$ and higher aspect ratio (80) in order to increase significantly the number of fibers per unit volume of concrete. For the experimental evaluation of the parameters that define the constitutive law for the simulation of the post-cracking behavior of SFRSCC, a minimum set of 9 specimens is recommended in order to avoid a high penalization in the process of deriving the design values from the characteristic ones.

If strain hardening fiber reinforced composites are used (i.e., advanced cement based materials with a tensile strength higher than the stress at crack initiation), the thickness of the FRC strengthening layer can eventually be decreased, maintaining high levels of flexural strengthening effectiveness, not only in terms of load carrying capacity but also in energy dissipation and ductility performance. A layer model section that includes constitutive models to simulate the relevant aspects of the behavior of the intervening 
materials was capable of predicting with good accuracy the maximum load registered in the experimental tests for ancient brick prototypes reinforced with a thin layer of SFRSCC. For a design framework, the constitutive law that simulates the post-cracking behavior of a FRC should be established according to the recommendations of the CEB-FIP Model Code 2010 (Comité Euro-International du Béton, 2010).

\section{ACKNOWLEDGEMENT}

The study reported in herein is part of the research program "PrePamPre-fabricated thin panels using advanced materials for structural rehabilitation", PTDC/ECM/114511/2009, supported by FCT. The authors would like to acknowledge the support provided by the Civitest Company, where the major part of the tests was carried out.

\section{REFERENCES}

American Concrete Institute (ACI). 1996. ACI 544.1R-96: State-of-the-art report on fiber reinforced concrete-Technical report. Farmington Hills, Michigan: ACI.

Balaguru, P. N., and S. P. Shah. 1992. Fiber reinforced cement composites. New York, NY: McGrawHill.

Barros, J. A. O., V. M. C. F. Cunha, A. F. Ribeiro, and J. A. B. Antunes. 2005. Post-cracking behaviour of steel fibre reinforced concrete. RILEM Materials and Structures Journal 38(275), 47-56.

Basto, C. A. A., and J. A. O. Barros. 2008. Numeric simulation of sections submitted to bending. Technical report 08-DEC/E-46. Guimarães, Portugal: Department of Civil Engineering, School of Engineering, University of Minho, pp. 73,

CEB-FIP. 2010. Model Code 2010. Final Draft, prepared by Special Activity Group 5, Edited by fib.

Cunha, V. M. C. F. 2010. Steel fibre reinforced self-compacting concrete: From micro-mechanics to composite behaviour. Doctoral Thesis Department of Civil Engineering, Minho University. Minho, Portugual.

Cunha, V. M. C. F., J. A. O. Barros, J. M. Sena-Cruz. 2010. Pullout behaviour of steel fibres in self-compacting concrete. ASCE Journal of Materials in Civil Engineering 22(1):

European Federation of National Associations Representing Producers and Applicators of Specialist Building Products for Concrete (EFNARC). 2002. Specification and guidelines for selfcompacting concrete. Surrey, UK: EFNARC, $32 \mathrm{pp}$.

Fernandes, F., and P. B. Lourenço. 2007. Evaluation of the compressive strength of ancient clay bricks using microdrilling. Journal of Materials in Civil Engineering 19(9):791-800.

German Institute for Standardization. 2000. DIN 1045-1: Concrete, reinforced and pre-stressed concrete structures. Part 1: Design [German version].

German Institute for Standardization. 2007. DIN EN 1015-11: Methods of test for mortar and masonry. Part 11: Determination of flexural and compressive strength of hardened mortar [German version].

German Institute for Standardization. 2000. DIN EN 1015-12: Methods of test for mortar and masonry. Part 12: Determination of adhesive strength of hardened rendering and plastering mortar on substrates [German version].

Häßler, D. 2010. Steel fibre reinforced self-compacting concrete thin layer for the flexural strengthening of ancient arch structures: Experimental and numerical research. Master's Thesis University of Minho. Minho, Portugal.

Krausz, K. 2002. Tragverhalten gemauerter Tonnengewölbe. Institut für Baustatik, Universität Stuttgart Doctoral Dissertation. Stuttgart, Germany. 
Marcari, G., D. Oliveira, and P. B. Lourenço. 2011. Durability analysis of FRP-masonry systems. In Proceedings of the Anidis 2011: L'Ingegneria Sismica in Italia.

Oliveira, F. L. 2010. Design-oriented constitutive model for steel fiber reinforced concrete. Doctoral Dissertation Universitat Politècnica de Catalunya. Barcelona, Spain.

Palácio, K., P. J. B. Lourenço, and J. A. O. Barros. 2003. Contribution to design criteria for industrialized masonry vaults. Technical report 03-DEC/E-10. Guimarães, Portugal: Department of Civil Engineering, School of Engineering, University of Minho, $46 \mathrm{p}$.

Pereira, E. B., J. A. O. Barros, and A. F. F. L. Camões. 2008. Steel fiber reinforced self-compacting concrete-Experimental research and numerical simulation. Journal of Structural Engineering 134(8):1310-1321.

RILEM TC. 1994. FMC1: Determination of fracture energy of mortar and concrete by means of three-point bend tests on notched beams, 1985. In RILEM Technical Recommendations for the Testing and Use of Construction Materials. London: E \& FN Spon.

RILEM TC. 2000. 162-TDF: Test and design methods for steel fibre reinforced concrete. In Materials and Structures 33, pp. 3-5.

Robins, P., S. Austin, and P. Jones. 2002. Pull-out behaviour of hooked steel fibres. RILEM Journal of Engineering Mechanics 35(251):434-442.

Shah, S. P., and L. Ferrara. 2008. Self consolidating fiber reinforced concrete. In Proceedings of the Seventh International RILEM Symposium on Fibre Reinforced Concrete: Design and Applications, ed., R. Gettu. Chennai, India:, pp. 641-659. 